\title{
A FUNDAMENTAL EVALUATION OF THE TOP FIVE SOUTH AFRICAN BANKS AFTER THE FINANCIAL CRISIS
}

\author{
Chris van Heerden* \\ North West University \\ Chris.vanheerden@nwu.ac.za \\ André Heymans" \\ North West University \\ Andre.heymans@nwu.ac.za
}

Received: July 2012

Accepted: September 2013

\begin{abstract}
A significant correlation exists between financial crises and bank liquidity problems, thus exposing the investor to increased risk where the banking industry forms part of their investment portfolios. Also, due to more volatile markets and more complex financing banking activities, the general notion of evaluating only share price trends to determine future investment prospects can become misleading. This paper, therefore, focuses on a multi-stage Data Envelopment Analysis (DEA) model as a complementary share performance tool to the traditional set of fundamental factors. When combining the results from the DEA model and a set of traditional financial measures, Nedbank and FirstRand were found to be the more sensible investment choices for the period under investigation.
\end{abstract}

Keywords

DEA, fundamental analysis, scale efficiency, technical efficiency

* Dr Chris van Heerden is a senior lecturer at the School of Economics, North West University, Potchefstroom, South Africa.

\# Dr André Heymans is a senior lecturer at the School of Economics, North West University, Potchefstroom, South Africa. 


\section{INTRODUCTION}

The South African financial industry is dominated by First National Bank, Nedbank, Standard Bank, Investec Bank, and ABSA Bank, which control approximately $90 \%$ of total banking assets in South Africa (SARB, 2010; 2011). The high level of competition in the domestic and international markets and the fundamental structural changes forcing organisations to be more flexible and productive encouraged banks to focus more on customer services (Hartle, 1997; Valenzuela, 2010). Historical studies have, however, questioned the level of efficiency and performance of the banking industry. Among these are: the lack of financial services provided for all (Hawkins, 2004); the inability to introduce new financial products (Akinboade \& Makina, 2006); operating costs outgrowing bank income (Hawkins, 2004); increasing staff costs (Bank Supervision, 2002); costly savings accounts (Hawkins, 2004); and customers not paying fair prices for financial services (Hawkins, 2004). These criticisms collectively highlight poor bank efficiency before the onset of the 2008 financial crisis. This is emphasised by the foreclosure of several South African banks due to liquidity problems. These banks include New Republic Bank (1996), FBC Fidelity (1999), Regal Treasury (2001) and Saambou Bank (2002). This evidence confirms that the South African banking industry is vulnerable to liquidity problems, despite being recognised as an industry of immense sophistication and reliability (Saayman, 2003).

The 2008 financial crisis hindered efforts to improve on banking performance, placing banks under unparalleled liquidity distress and limiting lending abilities (Aisen \& Franken, 2010). A principal reason for the severity of the financial crisis was the lack of sufficient liquidity buffers being held by banks (Acharya, Shin \& Yorulmazer, 2008). This was accompanied by the gradual erosion of the quality and level of banks' capital base and the build-up of excessive off- and on-balance sheet leverage. These failures were further amplified by the pro-cyclical deleveraging process and by the interconnectedness of systemic institutions through an array of complex transactions (BCBS, 2010). In order to address the market failures that were brought to light by the 2008 financial crisis, the Basel Committee for Banking Supervision (BCBS) introduced the new Basel III accord.

Nonetheless, the effects of the global crisis and the future implementation of the new Basel III accord will place enormous pressure on the current day-to-day activities of South African banks, signalling the possibility of declining future dividends and Returns on Equity (ROE) due to a deteriorating trend in headline earnings. For investors this can have significant effects on their current portfolio composition and future investment decisions, thus justifying the importance of revaluating the investment prospects in the South African banking industry. TABLES 1 to 3 (see appendix) sustain this argument, indicating that the global financial crisis had a significant effect on the performance of most of the top five South African banks. The dividend per share (see TABLE 1 in appendix) showed a substantial average decrease from 412.52 cents to 318.75 cents (2008 to 2010) for the top five banks, representing a decrease in profits that were distributed to shareholders. The earnings per share and the ROE (see TABLES 2 and 3 , respectively, in the appendix) also illustrated a considerable decrease in value between 2008 and 2010, leading to a decrease in market confidence from an investor's perspective. The earnings per share decreased from an average of 967.07 cents to 726.49 cents, whereas the ROE showed an average decrease from $20.68 \%$ to $13.80 \%$ for the top five South African banks. These results, therefore, highlight the uncertainty regarding the choice to invest in the South African banking industry. 
Consequently, the objective of this paper is to establish the current trend (increase or decrease) of South African bank performance from an investor's perspective. By assessing traditional financial ratios, the best investment options (banks) will be determined. These results will then be benchmarked with the results from a multi-stage Data Envelopment Analysis (DEA) model, which will also determine the best bank in terms of relative efficiency, and, most importantly, the order in which investors must conceive the top five banks as investment choices. The rest of the paper will proceed as follows: a literature review on traditional financial ratios as fundamental factors will be provided in section 2. This will be followed by a discussion on relative bank efficiency and the DEA model in section 3 , followed by the methodology in section 4 , an interpretation of the results in section 5 , and concluding remarks in section 6 .

\section{FUNDAMENTAL ANALYSIS}

Fundamental analysis can be considered as the process of analysing the industry, companyspecific and macroeconomic factors that influence the return-risk relationship of an investment (Marx, Mpofu, Van de Venter \& Nortje, 2006). The efficient market hypothesis considers fundamental analysis as an ineffective approach, because all information is already incorporated in share prices (Bodie, Kane \& Marcus, 2010). However, fundamental analysis can become more essential to identify investment opportunities in more volatile markets. The level of volatility, as illustrated by the SA Volatility Index (SAVI) in FIGURE 1, has increased substantially. Significant spikes in volatility were present during the crisis period and also during the post-crisis period, which could be due to the after-effects of the crisis. It can, therefore, be argued that more attention should be given to fundamental analysis to determine potential investment choices with greater certainty in a market with greater noise.

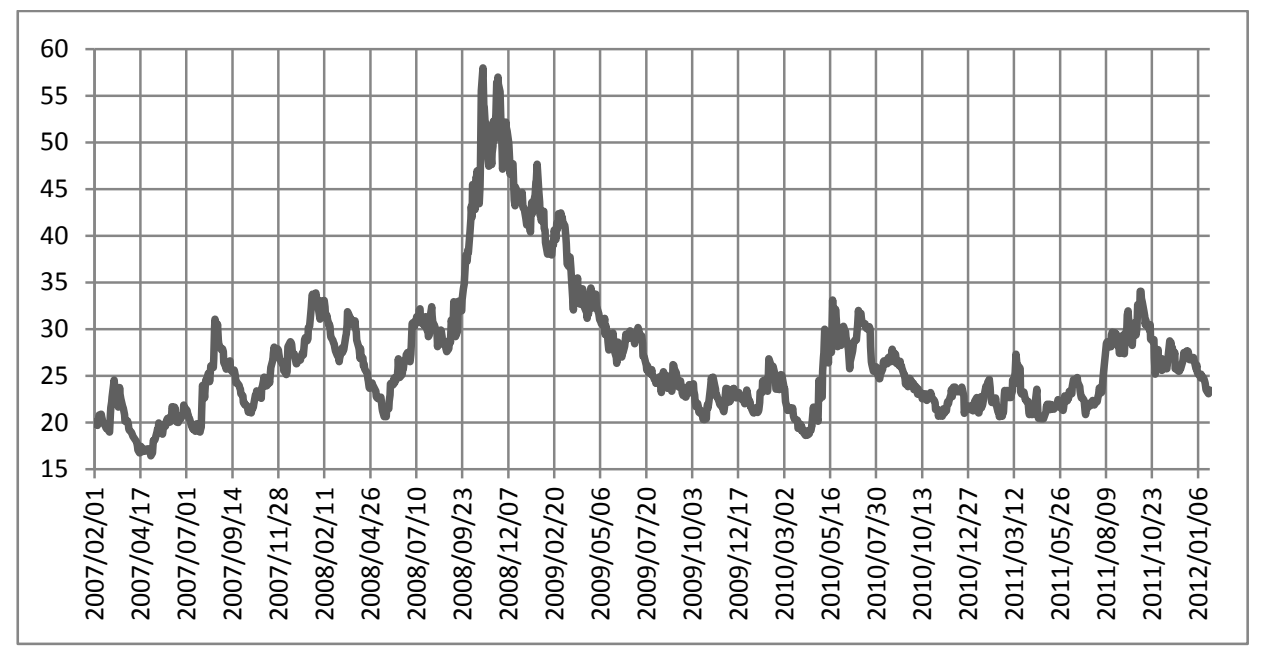

FIGURE 1: The SAVI index from January 2007- January 2012

Source: McGregor BFA database (2012).

The study by Menkhoff (1998) argues that fundamental analysis should be the basis for forecasts and decision-making by arbitrageurs. Although fundamental analysis is considered inefficient for some short-term strategies (MacDonald \& Taylor, 1992; Harvey, 1996), longer forecasting horizons assign greater importance to fundamental analysis (Menkhoff, 1997; Lui \& 
Mole, 1998). However, none of the previous studies considers non-financial measures as an additional fundamental analysis tool.

This paper's focus regarding fundamentals analysis is, therefore, to analyse a reflective combination of traditional financial and non-financial measures to assess the top five South African banks as investment opportunities. However, before the investigation can commence the concept of financial measures must first be understood from an investor's perspective. The American Accounting Association (1966:1) defined financial measures as a "process of identifying, measuring and communicating economic information to permit informed judgement and decisions by users of the information". By combining the information of a bank's income statements (statement of comprehensive income) and balance sheets (statement of financial position), the first step in relative bank performance evaluation can be initiated by means of ratio analyses.

The use of financial ratios in explaining cross-sectional returns abounds in the literature. The bulk of the work in this area has been done to separate value stocks from growth stocks, with the former outperforming the latter on average. Growth stocks are considered undervalued, and therefore have the potential to grow in value in the near future. Value stocks, on the other hand, are considered undervalued based on their $\mathrm{P} / \varepsilon$ and price-to-book ratios.

The results seem to be consistent across both developed countries as well as emerging economies. Stattman (1980), Rosenberg, Reid and Lanstein (1985) and Lakonishok, Shleifer and Vishny (1994), for example, found the average returns on stocks of the United States (US) to be positively related to the ratio of a firm's book value to its market value (BV/MV), while Basu (1983) proved that earnings-price ratios helped to explain cross sectional United States (US) returns. These results were also confirmed by Fama and French $(1992,1996)$, who proved that the ratio of a firm's BV/MV is positively related for various subsets of US returns. In related studies, Capaul, Rowley and Sharpe (1993) found that value stocks (based on price-to-book values) outperformed growth stocks for the US as well as other major European markets, while Chan, Hamao, and Lakonishok (1991) found that the BV/MV as well as the cash flow yield plays a strong role in explaining the cross-section of average returns on Japanese stocks. On the emerging market side Achour, Harvey, Hopkins and Lang (1998) found that value stocks also perform better than growth stocks in emerging economies. This was confirmed by Rouwenhorst (1999), who found that value stocks outperformed growth stocks for 20 emerging markets, when using book-to-market value as a proxy for value. Similar results were also found by Van der Hart, Slagter and Van Dijk (2003) as well as Senthilkumar (2009).

According to Lakonishok et al. (1994), this value premium (difference between value and growth stocks) is the result of the market undervaluing distressed stocks while overvaluing growth stocks. This imbalance is then equalised when 'incorrectly' priced 'value' stocks gain value over time. In contrast to the view of Lakonishok et al. (1994), Fama and French $(1993,1995,1996)$ reason that the value premium is the compensation for mispriced risk when applying the Capital Asset Pricing Model (CAPM).

Although historical studies may have emphasised the superior performance of value stocks and the use of this approach when selecting a profitable portfolio, this approach has a number of shortcomings that must be recognised. Firstly, the importance of measuring liquidity has become more acute since the 2008 financial crisis, which is not acknowledged by the abovementioned studies. Since banks were placed under unparalleled liquidity distress during the crisis, with South African banks being no exception, it emphasises the importance of incorporating a liquidity measure, like the current ratio, in the performance evaluation process. 
Secondly, one of the most important shortcomings is that financial measures are backwardlooking and do not reflect the long-term and future consequences of managerial actions (Clark, 1997). Using financial ratios as the sole measure for incentive purposes may also encourage only short-term managerial focus and may, therefore, distort the decision-making process (Kaplan \& Norton, 1996). This is because the nature of financial ratios is based only on internal historical data, which implies that they are of limited use for strategic decision-making and planning. Ratios are also not effective means of representing the many facets of performance (Avkiran, 1997) and are more sensitive to manipulation. The study by Davenport and Sherman (1987:35) emphasised this statement by stating that "ratios cannot capture the interplay among multiple resources and outputs". To overcome these shortcomings investors should consider the use of non-financial measures that provide more insight regarding bank efficiency as one aspect of overall firm performance, which can be measured with respect to an objective. This objective can be measured with respect to the maximisation of output, the maximisation of profits or the minimisation of costs (Mester, 2003).

\section{RELATIVE BANK EFFICIENCY AND THE DEA MODEL}

Efficiency must be acknowledged as only one aspect of overall performance which can be estimated by means of an objective that can include the maximisation of output, the maximisation of profits or the minimisation of costs (Mester, 1994). The level of efficiency can, therefore, be evaluated by several categories (for example, X-efficiency, scale efficiency and scope efficiency), where technical and scale efficiency will form the focus of this study. Technical efficiency refers to the ability of a bank to produce an optimal output level from each input level, which is also located on its optimal production frontier (Coelli, Rao \& Battese, 1998). This implies that if the bank is currently wasting its inputs it will be considered technically inefficient, whereas using the wrong combination of inputs to produce its outputs will mean that it will be considered allocatively inefficient. Scale efficiency, on the other hand, refers to the bank's ability to produce the most cost-efficient level of outputs (Mester, 1994). If a bank is operating at constant scale economies, it implies that a proportionate increase in its outputs would lead to a less than proportionate increase in cost. This means that the bank could produce more efficiently by increasing its output level. A bank operating at diseconomies of scale signifies that a proportionate decrease in its outputs would lead to a more than proportionate decrease in costs (Mester, 1994). This bank can be more effective by reducing its input level. The goal of being scale-efficient is, therefore, to be able to minimise average costs over the long-run that will allow the bank to be more competitive and able to expand its production capacity in the future.

These relative aspects of performance in terms of efficiency can play an essential role in the strategic planning process of investors regarding portfolio diversification. However, unpredicted factors in a performance model can still affect a bank's cost over a period (Mester, 1994). Some of these unpredicted factors include the possibility that the data are inaccurately measured and the unavailability of data. Banks' databases accommodate only accounting procedures and not combined analysis of operational, marketing and financial data. In order to overcome these problems the multi-stage DEA model will be applied in the measuring of banking performance. The modelling flexibility of the DEA and its ability to address qualitative and quantitative data, as well as non-discretionary and discretionary inputs, makes this model the most applicable model for this study (Golany \& Storbeck, 1999). The multi-stage DEA model is also able to overcome two shortcomings of the more commonly used two-stage linear programming (LP) 
process. Firstly, the two-stage LP process maximises the sum of slacks, where it should minimise it; and it identifies the furthest efficient point, where it should identify the nearest point. Secondly, the two-stage LP process is not invariant to the units of measurement (Lovell and Pastor, 1995; Coelli, 1998).

This technique is called DEA, because the data on the best-practice banks envelop the data completely from the rest of the banks in the sample (Avkiran, 1999). The DEA model has the ability to solve linear programming problems that generate a non-parametric, piecewise linear convex frontier that envelops the input and output data relative to which cost is minimised (Färe, Grosskopf \& Lovell, 1985). This frontier can, therefore, be used to measure the relative efficiency or productivity in terms of the inputs and outputs selected by the organisation (Avkiran, 1999). According to Premachandra, Bhabra and Sueyoshi (2009), the DEA model is a simple tool for assessing bankruptcy, as it is able to separate default and non-default firms. The DEA model also has the ability to determine:

- the best-practice and most productive group of service units;

- the less-productive service units compared to the best-practice units;

- the amount of excess resources used by each of the less-productive units;

- the amount of excess capacity or ability to increase service outputs in less-productive units without utilising added resources; and

- the set of best-practice service units most similar to the less-productive units (Sherman \& Ladino, 1995).

The DEA is also used because it lends itself more readily to multiple output analysis. DEA is useful in cases where the behavioural objective of the organisation is clouded by, for example, government regulations or operating constraints (Van der Westhuizen, 2006). The study by Sherman and Ladino (1995) elaborated on the advantages of the DEA model and found that the DEA is a powerful tool for service businesses, because it helps the organisation to identify the best practices in complex service operations. This includes service operations that are too complex for traditional analytical techniques and observations (Sherman \& Ladino, 1995). Also, the DEA model does not require any specifications on the functional form of the frontier, because it uses linear programming to construct the required piece-wise frontier that envelops all the observations. Finally, the DEA model has the ability to quantify inputs and outputs with different units of measurement and can consider multiple inputs and outputs simultaneously (Kirigia, Sambo \& Scheel, 2001). In order to estimate a DEA model the following three steps were established by Golany and Storbeck (1999). Firstly, a decision-making unit (DMU) must be selected to establish the best-practice bank that will be used as a benchmark. Secondly, the appropriate input and output combination that will be used in the DEA model must be chosen and finally, a mathematical formulation for the DEA model that will be applied in the study must be selected. The next section applies these steps and elaborates on the data and methodology.

\section{METHODOLOGY}

Efficiency scores can be helpful in exploring the effects and causes of performance (Schaffnit, Rosen \& Paradi, 1997). However, efficiency scores can be highly dependent on the choice of inputs and outputs (Berg, Forsund \& Jansen, 1991), especially given the difficulty of defining inputs and outputs in the banking industry (Mlima \& Hjalmarsson, 2002). With the multi-product nature of a banking firm there is still no agreement as to the definition and measurement of 
banks' inputs and outputs (Girardone, Molyneux \& Gardener, 2004). Nonetheless, the intermediation approach is used in this paper to measure the relative efficiency of the top five South African banks. The intermediation approach is the most appropriate approach for evaluating an entire bank, because it views financial institutions as mediators between the supply of and the demand for funds (Molyneux, Altunbas \& Gardener, 1996; Mester, 1996), and this approach is best suited for the available data (Elyasiani \& Mehdian, 1990).

The financial data of FirstRand Bank (proxy for First National Bank), Nedbank, Standard Bank, Investec and ABSA were obtained from the monthly BA 900 financial return statements on the South African Reserve Bank's website (SARB, 201la) from January 2008 to April 2012. This time span is based on the data available at the time when the empirical study commenced. The monthly total of each variable, which also forms the main entries in the financial return statements, is used as reported in the monthly BA 900 financial return statements (see item \# in TABLE 4 in the appendix). The deposits, loans and advances output variable excludes the South African bank group funding, which is used as an input variable. The contingent liabilities and other risk exposure output variable, on the other hand, include only guarantees on behalf of the clients, letters of credit, bankers' acceptances, committed undrawn facilities, and underwriting exposures. In addition, the DEAP (version 2.1) program developed by Coelli et al. (1998) was used to estimate the following multi-stage DEA model. In this DEA model consider $K$ as the number of inputs and $M$ as the number of outputs on each of $N$ bank, where for the $i$ th bank these inputs and outputs are represented by the vectors $x_{i}$ and $y_{i}$, respectively. The $M \times N$ output matrix will then be represented by $Y$ and the $K \times C$ input matrix will be represented by $X$. The constant returns to scale, input-orientated, DEA model that is subjected to a multi-stage methodology can then be illustrated by the following steps, with minor changes to this approach when applying a variable returns to scale approach (Coelli, 1998):

In the first step, conduct a radial LP process with the following form:

$$
\begin{array}{ll}
\min & \theta \\
\theta, \lambda & \\
\text { s.t. } & -y_{i}+Y \lambda \geq 0, \\
& \theta x_{i}-X \lambda \geq 0, \\
& \lambda \geq 0,
\end{array}
$$

where $\theta$ is a scalar and $\lambda$ denotes a $N \times 1$ vector of constants. This process is continued for $N$ times, therefore, generating a $\theta$ for each of the banks.

In the second step, this process is then followed by a second stage LP process where the sum of any remaining slacks is maximised, which can be illustrated as follows (Coelli, 1998):

$$
\begin{array}{ll}
\max & \left(M 1^{\prime} O S+K 1^{\prime} I S\right) \\
\lambda, O S, I S & \\
\text { s.t. } \quad & -y_{i}+Y \lambda-O S=0, \\
& c x_{i}-X \lambda-I S=0, \\
& \lambda \geq 0, O S \geq 0, I S \geq 0
\end{array}
$$

where $c x_{i}$ denotes the input vector of the $i$ th bank, which has been multiplied by the $\theta$ (being contracted) from step 1; OS denotes the $M \times 1$ vector of output slacks; $I S$ denotes the $K \times 1$ vectors of input slacks; and $K 1$ and $M 1$ are $K \times 1$ and $M \times 1$ vectors of ones, respectively. This process is continued for $N$ times, where after all the banks with no slacks and those that have a technical efficiency score of $\theta=1$ are identified and classed as the 'efficient banks'. This 
process is also duplicated for all banks with non-zero slack variables and is then classed as the 'banks with slacks' set. The banks with slacks' set will then be used to estimate a sequence of radial movements, based on projected points estimated in step 1 , in order to obtain the projected point on the efficient frontier, whereas the 'efficient banks' will be used only as a reference in the LP estimations from this stage on (Coelli, 1998).

The third step will be to conduct a sequence of $K$ LPs, in order to identify only all input dimensions which contain slacks, of the $i$ th bank in the 'banks with slacks' set. This step will, however, break down if some inputs are found to be zero. In this process each LP will allow contractions in only one of the inputs, which will determine the presence of potential slacks within these inputs. The LP for the $j$ th input of the $i$ th bank can, therefore, be illustrated as follows (Coelli, 1998):

$$
\begin{array}{ll}
\min & \theta \\
\theta, \lambda & \\
\text { s.t. } & -y_{i}+Y_{e} \lambda \geq 0, \\
& \theta c x_{i}^{j}-X_{e}^{j} \lambda \geq 0, \\
& c x_{i}^{\neq j}-X_{e}^{\neq j} \lambda \geq 0, \\
& \lambda \geq 0,
\end{array}
$$

where $c x_{i}^{j}$ denotes the $j$ th input of the $i$ th bank, which is multiplied by $\theta$ (being contracted) that is obtained from step $1 ; X_{e}^{j}$ denotes the $1 \times N_{e}$ vector of the $j$ th inputs of all the efficient banks; $c x_{i}^{\neq j}$ denotes the $(K-1) \times 1$ vector of inputs of the $i$ th bank, which excludes the $j$ th input that is then contracted by being multiplied by $\theta$, as obtained in equation $1 ; X_{e}^{\neq j}$ denotes the $(K-$ 1) $\times N_{e}$ matrix of inputs of all the efficient banks, also excluding the $j$ th input; $N_{e}$ denotes the number of efficient banks as already identified in step 2; $Y_{e}$ denotes the matrix of outputs of the efficient banks; and $\lambda$ has a dimension of $N_{e} \times 1$ (Coelli, 1998).

The fourth step includes estimating a LP for the $i$ th bank in the 'banks with slacks' set, which seek a radial reduction in all inputs that were already identified during step 3 as having potential slacks. This estimation can be illustrated as follows (Coelli, 1998):

$$
\begin{array}{ll}
\min & \theta \\
\theta, \lambda & \\
\text { s.t. } & -y_{i}+Y_{e} \lambda \geq 0, \\
& \theta c x_{i}^{s}-X_{e}^{s} \lambda \geq 0, \\
& c x_{i}^{n s}-X_{e}^{n s} \lambda \geq 0, \\
& \lambda \geq 0
\end{array}
$$

where $s$ denotes the subset of inputs that have potential slacks; and $n s$ denotes the remainder of the inputs used. Remember that the radial reduction in this specific step starts by applying the projected point $\left(y_{i}, c x_{i}\right)$ that was already estimated during step 1.

With the fifth step it is still possible for some inputs slacks to remain after the radial reduction in the previous step. To overcome this problem, steps 3 and 4 must be repeated with the projected point, which was already identified during step 4 , until no remaining input slacks are present (Coelli, 1998).

In the sixth step, a radial expansion in the output slack dimensions is conducted until no output slacks remain. This can be accomplished by taking the projected points of the $i$ th bank, as 
estimated in step 5 , and repeating steps 3 to 5 . The final projected point from this step, which will be invariant to the units of measurements that were chosen, will be on the efficient surface. The slacks can then be estimated by subtracting the final projected point in this step from the projected point that was obtained in step 1 . Also, the peers of the $i$ th bank can be identified from the $\lambda$ vector of the final projected point (Coelli, 1998).

Under the multi-stage DEA model technical and scale efficiency can be estimated under an input- or output-orientated approach. The input-orientated approach characterises the production technology of the bank, regarding the production of a given output mix with the minimum inputs (Coelli et al., 1998). The output-orientated approach, on the other hand, characterises a bank in pursuit of producing the maximum output bundle with the given input mix (Coelli et al., 1998). Furthermore, the input- and output-orientated approach can be estimated under a Constant Return to Scale (CRS) framework or a Variable Returns to Scale (VRS) framework. CRS refers to the proportional increase in outputs due to an increase in inputs (Avkiran, 1999), whereas VRS refers to the disproportional increase or decrease in outputs when the inputs increase (Avkiran, 1999). The CRS framework will not function properly under conditions such as imperfect competition and constraints on finance, which implies that banks will be unable to operate at their optimal scale (Coelli et al., 1998). However, despite the limitation of the CRS framework it is still recommended that the DEA model must be estimated under both the CRS and VRS frameworks separately, and then compared in terms of the efficiency scores generated (Coelli et al., 1998). The efficiency scores generated from the CRS framework represents technical efficiency that measures the inefficiencies due to the size of operations and the banks' input-output combination (pure scale efficiency). The efficiency scores generated from the VRS framework, on the other hand, represent pure technical efficiency that measures efficiency without scale efficiency (Avkiran, 1999). The difference between the CRS efficiency scores and the VRS efficiency scores will, therefore, present a potential scale inefficiency measurement. This leads to the following section, which will report the results found by applying the steps discussed above.

\section{RESULTS}

By evaluating the yearly returns (as a percentage change in share price), the $P / \varepsilon$ ratio, the price-to-book value, the cash flow yield and the current ratio value as a reflective combination of traditional financial measures, with their applicability justified by the literature study, the following results were found as reported in TABLES 5 and 6 .

The results reported in TABLE 5 illustrate that Investec, Nedbank and FirstRand are the top three performing banks, and can therefore be considered as possible investment prospects. The overall ranking was determined by formulating an index where each bank received a ranking from one to five for each financial measure, with one illustrating the best. 
TABLE 5: Summary of the financial measures (ranked from best to worst)

\begin{tabular}{|c|c|c|c|c|}
\hline & 2008 & 2009 & 2010 & 2011 \\
\hline \multirow{5}{*}{$P / E$ ratio } & Nedbank & Investec & FirstRand & ABSA \\
\hline & FirstRand & FirstRand & Nedbank & Nedbank \\
\hline & Investec & ABSA & ABSA & FirstRand \\
\hline & ABSA & Nedbank & Investec & Standard Bank \\
\hline & Standard Bank & Standard Bank & Standard Bank & Investec \\
\hline \multirow{5}{*}{$\begin{array}{l}\text { Price-to-book } \\
\text { value }\end{array}$} & Investec & Investec & Investec & Investec \\
\hline & Nedbank & Nedbank & Nedbank & Nedbank \\
\hline & Standard Bank & FirstRand & ABSA & Standard Bank \\
\hline & ABSA & Standard Bank & Standard Bank & ABSA \\
\hline & FirstRand & ABSA & FirstRand & FirstRand \\
\hline \multirow{5}{*}{ Cash flow yield } & Investec & Investec & Investec & Investec \\
\hline & Standard Bank & FirstRand & ABSA & FirstRand \\
\hline & ABSA & Nedbank & Nedbank & Standard Bank \\
\hline & Nedbank & ABSA & FirstRand & Nedbank \\
\hline & FirstRand & Standard Bank & Standard Bank & ABSA \\
\hline \multirow{5}{*}{ Current ratio } & Investec & Investec & Investec & Investec \\
\hline & FirstRand & FirstRand & FirstRand & Nedbank \\
\hline & Standard Bank & Standard Bank & Standard Bank & FirstRand \\
\hline & ABSA & ABSA & ABSA & Standard Bank \\
\hline & Nedbank & Nedbank & Nedbank & ABSA \\
\hline
\end{tabular}

Source: Compiled by the authors with data from the McGregor BFA database (2012)

See TABLES 10 to 13 in the appendix for the complete results.

The total for each bank over each year was then estimated, after which the average over the entire period under investigation was determined. The bank with the lowest average rating was then considered as the top-performing bank, based on all the financial measures used (see TABLE 9 in the appendix). The fundamental analysis of these banks illustrates that their shares are undervalued, which implies that the share price could show a further increase in the near future. The yearly returns from 2008 to April 2012 (TABLE 6) corroborate this, where Investec exhibited a poor growth in share price between 2008 and April 2012, emphasising the possibility that it might be undervalued. There is also evidence of a strong historical trend in Investec's performance (based on the financial measures where Investec ranked first; see TABLE 9 in the appendix), confirming this share's promise of future growth. Nonetheless, Nedbank's share price grew by $77.47 \%$ and that of FirstRand by $56.86 \%$, respectively, which is considerably more compared to their peers. 
TABLE 6: Summary of yearly returns

\begin{tabular}{llllll}
\hline & ABSA & FirstRand & Investec & Nedbank & Standard Bank \\
2008 & $-2.57 \%$ & $-18.43 \%$ & $-35.65 \%$ & $-29.78 \%$ & $-17.07 \%$ \\
2009 & $18.82 \%$ & $13.84 \%$ & $26.82 \%$ & $29.90 \%$ & $22.89 \%$ \\
2010 & $8.95 \%$ & $6.38 \%$ & $5.46 \%$ & $5.08 \%$ & $5.44 \%$ \\
2011 & $0.71 \%$ & $6.30 \%$ & $-21.53 \%$ & $11.24 \%$ & $-8.18 \%$ \\
Until April 2012 & $13.48 \%$ & $21.84 \%$ & $1.27 \%$ & $16.88 \%$ & $16.20 \%$ \\
Growth from 2008 - April 2012 & $47.94 \%$ & $56.86 \%$ & $6.29 \%$ & $77.47 \%$ & $38.25 \%$ \\
\hline
\end{tabular}

Source: Compiled by the authors with data from the McGregor BFA database (2012)

Though Nedbank ranked second, based on the financial ratios that were consulted (see TABLE 9 in the appendix), it still surpassed all the other banks in terms of share price performance over the period under investigation, making it a more convincing and more desirable investment to consider.

Furthermore, although ABSA shows potential in terms of the $P / \varepsilon$ ratio, it failed to provide a good overall ranking (ranked fourth according to TABLE 9 in the appendix). Also, Standard Bank exhibited the weakest performance of all the South African banks under investigation, making it the least attractive investment option. On the upside, Standard Bank exhibited the thirdhighest increase in yearly returns (16.20\%) from the end 2011 to April 2012, and also made a significant recovery $(38.25 \%)$ after the financial crisis, making it a viable choice for a more speculative strategy. The same can be said for ABSA, where it exhibited an increase of $13.48 \%$ in yearly returns, and an overall recovery of $47.94 \%$ after the financial crisis. Overall, from these results the conclusion can be drawn that Nedbank and FirstRand would be the more rational investment choice, based on this specific group of financial measures.

In order to emphasise the results found from the financial measures, a DEA model subjected to a multi-stage methodology is estimated to incorporate operational efficiencies that financial measures are unable to reflect. From the results reported in TABLES 7 and 8 it is evident that the principal bank to invest in is Standard Bank, with an average technical and scale efficiency estimate of 0.99 and 1.00 (input- and output-orientated), respectively. Standard Bank had fewer fluctuations over the 52-month period, with 38 months (input-and output-orientated) being totally technically efficient and 48 months ( 47 months) of being totally scale-efficient, according to the input-orientated approach (output-orientated) (see FIGURES 2 to 5 and TABLE 15 in the appendix). The results indicate that Standard Bank can increase its technical efficiency by $1 \%$ by changing its input level and by utilising the inputs more efficiently (TABLE 7). Standard Bank was at an increasing return to scale for three months (input-orientated) and for one month (output-orientated), implying that it was operating at too small a scale (TABLE 8). It was also at a decreasing return to scale for 11 months (input-orientated) and for 12 months (output-orientated), indicating that it was operating at a scale that was too large. Conceivably, Standard Bank should be considered as the first choice from a speculative perspective, as it illustrates potential growth in terms of overall operational efficiency that could lead to an increase in future returns, whereas it still fails to provide a profound performance perspective from the traditional financial measures' point of view, where it ranked fifth on the overall ranking (see TABLE 9 in the appendix). 
The second choice, according to the multi-stage DEA model, would be ABSA Bank, because it shows less fluctuation in terms of scale and technical efficiency, with an average technical and scale efficiency estimate of $0.98,1.00$ (input-orientated) and 0.98, 0.99 (output-orientated), respectively (see FIGURES 2 to 5 and TABLE 14 in the appendix). These estimates therefore illustrate that there is still room to enhance the utilisation of its inputs. ABSA Bank was at an increasing return to scale for six months (input-orientated) and for two months (outputorientated), implying that it was operating at too small a scale (TABLE 8). It was also at a decreasing return to scale for 18 months (input-orientated) and for 26 months (outputorientated), indicating that it was operating at a scale that was too large. However, besides the verification of operational efficiency, $A B S A$ was ranked fourth in terms of the financial measures (see TABLE 9 in the appendix) and lacks the consistency in terms of respectable yearly returns. These results, therefore, make ABSA and Standard Bank possibilities for a more speculative trading strategy based on the potential for significant internal operational efficiency, which could lead to greater future returns.

TABLE 7: Summary of the average efficiency results

\begin{tabular}{|c|c|c|c|c|c|c|c|}
\hline \multicolumn{2}{|c|}{ Input-orientated } & \multicolumn{2}{|c|}{ Output-orientated } & \multicolumn{2}{|c|}{ Input-orientated } & \multicolumn{2}{|c|}{ Output-orientated } \\
\hline Name & $\begin{array}{l}\text { Technical } \\
\text { efficiency }\end{array}$ & Name & $\begin{array}{l}\text { Technical } \\
\text { efficiency }\end{array}$ & Name & $\begin{array}{c}\text { Scale } \\
\text { efficiency }\end{array}$ & Name & $\begin{array}{c}\text { Scale } \\
\text { efficienc } \\
y\end{array}$ \\
\hline $\begin{array}{l}\text { Standard } \\
\text { Bank }\end{array}$ & 0.99 & $\begin{array}{l}\text { Standard } \\
\text { Bank }\end{array}$ & 0.99 & $\begin{array}{l}\text { Standard } \\
\text { Bank }\end{array}$ & & $\begin{array}{l}\text { Standard } \\
\text { Bank }\end{array}$ & \\
\hline ABSA & 0.98 & ABSA & 0.98 & ABSA & 1.00 & FirstRand & \\
\hline FirstRand & 0.94 & FirstRand & 0.95 & FirstRand & & ABSA & \\
\hline Nedbank & 0.93 & Nedbank & 0.93 & Investec & 0.99 & Investec & \\
\hline Investec & 0.90 & Investec & 0.90 & Nedbank & 0.98 & Nedbank & 0.97 \\
\hline
\end{tabular}

Source: Authors' compilation

See TABLES 14 to 18 in the appendix for the complete results.

TABLE 8: Summary of the average efficiency results

\begin{tabular}{|c|c|c|c|c|c|c|c|c|}
\hline & \multicolumn{4}{|c|}{ Input-orientated approach } & \multicolumn{4}{|c|}{ Output-orientated approach } \\
\hline & \multirow{2}{*}{$\begin{array}{l}\text { Technical } \\
\text { efficient }\end{array}$} & \multicolumn{3}{|c|}{ Scale efficiency } & \multirow{2}{*}{$\begin{array}{l}\text { Technical } \\
\text { efficient }\end{array}$} & \multicolumn{3}{|c|}{ Scale efficiency } \\
\hline & & Efficient & Increasing & Decreasing & & Efficient & Increasing & Decreasing \\
\hline ABSA & 25 & 40 & 6 & 18 & 26 & 33 & 2 & 26 \\
\hline Standard Bank & 38 & 48 & 3 & 11 & 38 & 47 & 1 & 12 \\
\hline Nedbank & 13 & 22 & 1 & 39 & 13 & 17 & 0 & 40 \\
\hline FirstRand & 10 & 48 & 31 & 10 & 10 & 41 & 10 & 22 \\
\hline Investec & 18 & 28 & 32 & 3 & 18 & 39 & 17 & 14 \\
\hline
\end{tabular}

Source: Authors' compilation

See TABLES 14 to 18 in the appendix for the complete results. 
Further results also illustrate that Nedbank and Investec Bank had a higher level of fluctuation in terms of scale and technical efficiency between 2008 and 2011, compared to Standard Bank (see FIGURES 2 to 5 in the appendix). Although Nedbank shows a considerable high level of fluctuations between 2008 and April 2010, it has more stability after April 2010 in terms of technical and scale efficiency, resulting in an average estimate for technical efficiency of 0.93 (input- and output-orientated) and for scale efficiency 0.98 (input-orientated) and 0.97 (output-orientated), respectively. These results may illustrate that Nedbank suffered more under the effects of the 2008 global financial crisis, which is emphasised by the lowest yearly returns in 2010 (5.08\%). These fluctuations in efficiency can be seen in TABLE 8, where Nedbank was at a decreasing return to scale for 39 months (input-orientated) and for 40 months (output-orientated), indicating that it was operating at a scale that was too large. Nonetheless, with the presence of stability in terms of scale and technical efficiency after the financial crisis, Nedbank illustrates consistency in its operations that can lead to greater future income levels, which can also be justified by the positive yearly returns all throughout the period under investigation, compared to its peers (TABLE 6). Also, according to the financial measures Nedbank has a superior market standing (ranked second, see TABLE 9 in the appendix), illustrating stable financial performance and growth potential. Investec, on the other hand, exhibits a significant level of fluctuation in terms of technical efficiency, but illustrates greater efficiency in terms of scale efficiency. Over the 52 -month period under investigation Investec was at an increasing return to scale for 32 months (input-orientated) and for 17 months (output-orientated), implying that it was operating at too small a scale (TABLE 8). These results, therefore, emphasise the possibility for Investec to improve on its performance by improving its management in terms of cost efficiency. Nonetheless, Investec still shows good performance in terms of the overall scale and technical efficiency, illustrating an average of 0.99 and 0.90 (input- and output-orientated), respectively. This puts Investec in front of ABSA and Standard Bank (ranked first, see TABLE 9 in the appendix) as an investment choice, but after FirstRand and Nedbank based on its poor share price performance.

Finally, based on the results found by the financial measures and the multi-stage DEA model, the conclusion can be drawn that FirstRand may be equally desirable as Nedbank. Although FirstRand showed a substantial higher level of volatility in terms of technical efficiency after January 2010 (see FIGURES 2 and 5 in the appendix), it was totally scale-efficient more times than Nedbank; it had a higher average scale and technical efficiency (input- and outputorientated) over the entire period under investigation; it had a higher yearly return (21.84\%) between 2011 and April 2012; and it exhibited a higher ROE (see TABLE 3 in the appendix) than Nedbank between 2008 and 2011. Also, based on the second highest yearly returns from 2008 to April 2012 (56.86\%) and its stable performance in scale efficiency, FirstRand can still be considered as an attractive investment option, which is equally as competitive as Nedbank.

To conclude, by evaluating both financial and non-financial (DEA) measures, from a fundamental analyses approach, evidence was found that Nedbank and FirstRand are the more logical investment choices over the period under investigation. Nedbank had the most consistency and less fluctuation in terms of technical and scale efficiency after September 2010 and stronger yearly returns over the entire period under investigation. It was also ranked under the top three banks in terms of the overall financial measure rankings, where it still performed the worst with the cash flow yield. Investec also performed significantly in terms of the financial measures (ranked first, see TABLE 9 in the appendix) and consistency in its scale efficiency (TABLE 7), although it illustrated a more inconsistent level of technical efficiency. 
In the end, FirstRand and Nedbank exhibited similar performance in terms of the financial measures and the yearly returns. FirstRand had a higher level of volatility in terms of technical efficiency during the later period under investigation, but was completely scale-efficient more times than Nedbank and exhibited a higher average scale and technical efficiency over the entire period under investigation compared to Nedbank. ABSA and Standard Bank should also not be neglected, as these banks show potential for a more speculative strategy. Standard Bank is the more dominant option in terms of overall efficiency, which could lead to higher future returns, but ABSA in terms of the financial measures that emphasise a relative better historical performance trend.

\section{CONCLUSION}

With volatile markets, investors will struggle to determine the appropriate buy and sell signals with the use of technical analysis, emphasising the importance of employing a fundamental analysis approach, which is the focus of this study. Furthermore, past empirical studies have considered only traditional financial measures in their fundamental analyses, but financial measures are considered to be backward-looking and easy to manipulate. They also fail to incorporate internal operations such as resource allocation. In order to overcome this failure, we incorporate the technical as well as the scale efficiency of the banks under observation. This allows for the incorporation of a forward-looking approach to portfolio management.

Measuring the relative efficiency of a bank can, therefore, serve as an additional preliminary performance measure to assist future decision-making processes in portfolio management. Together with the traditional fundamental factors such as the yearly returns, cash flow yield, price-to-earnings ratio, price-to-book and current ratio, a multi-stage DEA model was used as a tool to select shares based not only on past performances, but also on the bank's ability to utilise its resources efficiently towards future growth. The results of the evaluation of both financial and non-financial (DEA) measures make it evident that Nedbank and FirstRand held the most promise over the period under investigation.

Although this conclusion is backed by both fundamental factors as well as a multi-stage DEA, further research might also explore such a ranking system with the incorporation of other riskadjusted performance measures. This might allow investors to distinguish between different risk classes while getting an idea of potential growth in the future.

\section{LIST OF REFERENCES}

Acharya, V.V., Shin, H.S. \& Yorulmazer, T. (2008). Fire sales, foreign entry and bank liquidity. CEPR Discussion Paper 6309. [Online] Available: http://archive.nyu.edu/bitstream/2451/27881/2/wpa08035.pdf. (Accessed 13 July 2012)

Achour, D., Harvey, C.R., Hopkins, G. \& Lang, C. (1998). Stock selection in emerging markets: Portfolio strategies for Malaysia, Mexico, and South Africa. Emerging Markets Quarterly, 2, pp. 38-91.

Aisen, A. \& Franken, M. (2010). Bank credit during the 2008 financial crisis: A cross-country comparison. IMF working paper: WP/10/47. [Online] Available: http://www.imf.org/external/pubs/ft/wp/2010/wp1047.pdf. (Accessed 13 July 2012) 
Akinboade, 0.A. \& Makina, D. (2006). Financial sector development in South Africa, 1997-2002. Studies in Economics and Econometrics, 30(1), pp. 101-127.

American Accounting Association. (1966). American accounting association, a statement of basic accounting theory:1. Evanston Illinois: American Accounting Association.

Avkiran, N.K. (1997). Models of retail performance for bank branches: Predicting the level of key business drivers. International Journal of Bank Marketing, 15(6-7), pp. 224-237.

Avkiran, N.K. (1999). An application reference for Data Envelopment Analysis in branch banking: Helping the novice researcher. International Journal of Marketing, 17(5), pp. 206-220.

Bank Supervision. (2002). Annual report. Pretoria: South African Reserve Bank.

Basu, S. (1983). The relationship between earnings yield, market value, and return for NYSE common stocks: Further evidence. Journal of Financial Economics, 12(1), pp. 129-156.

BCBS (Basel Committee for Banking Supervision). 2010. Basel III: A global regulatory framework for more resilient banks and banking systems. June 2011. [Online] Available:

http://www.bis.org/publ/bcbs 189.pdf. (Accessed: 10 July 2012)

Berg, S.A., Forsund, F.R. \& Jansen, E.S. (1991). Technical efficiency of Norwegian banks: the nonparametric approach to efficiency measurement. Journal of Productivity Analysis, 2(2), pp. 127-142.

Bodie, Z. Kane, A. \& Marcus, A.J. (2010). Essentials of Investments, $8^{\text {th }}$ edition. Mass: Irwin/McGrawHill.

Capaul, C., Rowley, I. \& Sharpe, W.F. (1993). International value and growth stock returns. Financial Analysts Journal, 49(1), pp. 27-36.

Chan, L.K.C., Hamao, Y. \& Lakonishok, J. (1991). Fundamentals and stock returns in Japan. The Journal of Finance, 46(5), pp. 1739-1764.

Clark, P. (1997). The balanced scorecard. Accountancy Ireland, 29(6), pp. 25-26.

Coelli, T. (1998). A multi-stage methodology for the solution of orientated DEA models. Operations Research Letters, 23(3), pp. 143-150.

Coelli, T., Rao, D.S.P. \& Battese, G. (1998). An introduction to efficiency and productivity analysis. Boston: Kluwer Academic Publishers.

Davenport, T.O. \& Sherman, H.D. (1987). Measuring brance profitability. The Banker's Magazine, 170(5), pp. 37-38.

Elyasiani, E. \& Mehdian, S.M. (1990). A non-parametric approach to measurement of efficiency and technological change: the case of large US commercial banks. Journal of Financial Services Research, 4(2), pp. 157-168.

Fama, E.F. \& French, K.R. (1992). The cross-section of expected stock returns. The Journal of Finance, 47(2), pp. 427-465.

Fama, દ.F. \& French, K.R. (1993). Common risk factors in the returns on stocks and bonds. Journal of Financial Economics, 33(1), pp. 3-56.

Fama, દ.F. \& French, K.R. (1995). Size and Book-to-market factors in earnings and returns. The Journal of Finance, $50(1)$, pp. 131-155.

Fama, E.F. \& French, K.R. (1996). Multifactor explanations of asset pricing anomalies. The Journal of Finance, 51(1), pp. 55-84. 
Färe, R., Grosskopf, S. \& Lovell, C.A.K. (1985). The measurement of efficiency of production. Boston: Kluwer-Nijhoff.

Girardone, C., Molyneux, P. \& Gardener, E.P.M. (2004). Analysing the determinants of bank efficiency: The case of Italian banks. Applied Economics, 36(3), pp. 215-227.

Golany, B. \& Storbeck, J. (1999). A Data Envelopment Analysis of the operational efficiency of bank branches. Interfaces, 29(3), pp. 14-26.

Hartle, F. (1997). Transforming the performance management process. London: Clays Ltd, Kogan Page.

Harvey, J.T. (1996). Long-term exchange rate movements: The role of the fundamentals in neoclassical models of exchange rates. Journal of Economic /ssues, 30(2), pp. 509-516.

Hawkins, P. (2004). South Africa's financial sector ten years on: Performance since democracy. Development South Africa, 21 (1), pp. 179-204.

Kaplan, R.S. \& Norton, D.P. (1996). The balanced scorecard as a strategic management system. Harvard Business Review, 74, pp. 75-79.

Kirigia, J. M., Sambo, L. G. \& Scheel, H. (2001). Technical efficiency of public clinics in Kwazulu-Natal province of South Africa. East-African medical journal, 78(3), pp. 1-13.

Lakonishok, J., Shleifer, A. \& Vishny, R.W. (1994). Contrarian investment, exploration, and risk. The Journal of Finance, 49(5), pp. 1541-1578.

Lovell, C.A.K. \& Pastor, J.T. (1995). Units invariant and translation invariant DEA models. Operations Research Letters,18(3), pp. 147-152.

Lui, Y. \& Mole, D. (1998). The use of fundamental and technical analyses by foreign exchange dealers: Hong Kong evidence. Journal of International Money and Finance, 17(3), pp. 535-545.

MacDonald, R. \& Taylor, M.P. (1992). Exchange rates economics: A survey. International Monetary Fund staff papers, 39(1), pp. 1-57.

McGregor BFA database. (2012). Supplier of data. [Online] Available:

https://expert.mcgregorbfa.com/. (Accessed 13 July 2012)

Marx. J., Mpofu, R., Van de Venter, G. \& Nortje, A. (2006). Investment management. $2^{\text {nd }}$ ed. Pretoria: Van Schaik.

Menkhoff, L. (1997). Examining the use of technical currency analysis. International Journal of Finance and Economics, 2(4), pp. 307-318.

Menkhoff, L. (1998). The noise trading approach - questionnaire evidence from foreign exchange. Journal of International Money and Finance, 17(3), pp. 547-564.

Mester, L.J. (1994). Efficiency of banks in the third Federal Reserve district. Federal Reserve Bank of Philadelphia, Working Paper, 94-1, pp. 3-18.

Mester, L.J. (1996). A study of bank efficiency taking into account risk-preferences. Journal of banking and finance, 20(6), pp. 1025-1045.

Mester, L.J. (2003). Applying efficiency measurement techniques to central banks. Federal Reserve Bank of Philadelphia, Working Paper, 03-13, pp. 1-40.

Mlima, A.P. \& Hjalmarsson, L. (2002). Measurement of inputs and outputs in the banking industry. Tanzanet Journal, 3(1), pp. 12-22. 
Molyneux, P., Altunbas, Y. \& Gardener, E.P.M. (1996). Efficiency in European banking. New York: Wiley. Premachandra, I.M., Bhabra, G.S. \& Sueyoshi, T. (2009). DEA as a tool for bankruptcy assessment: A comparative study with logistic regression technique. European Journal of Operational Research, 193(2), pp. 412-424.

Rouwenhorst, K.G. (1999). Local return factors and turnover in emerging stock markets. The Journal of Finance, 54(4), pp. 1439-1464.

Rosenberg, B., Reid, K. \& Lanstein, R. (1985). Persuasive evidence of market inefficiency. Journal of Portfolio Management, 11 (3), pp. 9-17.

Saayman, A. (2003). Securitisation and bank liquidity in South Africa. [0nline] Available: http://www.essa.org.za/download/2003Conference/SaaymanA_Securitisation\%20And\%20Bank\%20L iquidity\%20In\%20South\%20Africa.pdf. (Accessed 13 July 2012)

Schaffnit, C., Rosen, D. \& Paradi, J.C. (1997). Best practice analysis of bank branches: an application of DEA in a large Canadian bank. European Journal of Operational Research, 98(2), pp. 269-289.

Senthilkumar, G. (2009). Behaviour of stock return in size and market-to-book ratio - Evidence from selected Indian industries. Journal of Finance and Economics, 33, pp. 142-153.

Sherman, D. \& Ladino, G. (1995). Managing bank productivity using Data Envelopment Analysis (DEA). Interfaces, 25(2), pp. 60-73.

South African Reserve Bank (SARB). (2010). South African banking sector overview. [Online] Available: www.banking.org.za/getdoc/getdoc.aspx?docid=1130. (Accessed 13 July 2012)

South African Reserve Bank (SARB). (2011). South African banking sector overview. [Online] Available: http://www.banking.org.za/getdoc/getdoc.aspx?docid=1175. (Accessed 13 July 2012)

South African Reserve Bank (SARB). (201la). [Online] Available:

http://www.resbank.co.za/RegulationAndSupervision/BankSupervision/Banking\%20sector\%20data/ Pages/Banks-BA900-Returns.aspx. (Accessed 13 July 2012)

Stattman, D. (1980). Book values and stock returns. The Chicago MBA: A Journal of Selected Papers 4 , pp. $25-45$.

Valenzuela, F. (2010). Switching barriers used to retain retail banking customers: Some empirical evidence from a South African country. Management Research Review, 33(7), pp. 749-766.

Van der Hart, J., Slagter, E. \& Van Dijk, D. (2003). Stock selection strategies in emerging markets. Journal of Empirical Finance, 10(1), pp. 105-132.

Van der Westhuizen, G. (2006). Estimating technical and scale efficiency of banks using balance sheet data: A South African case. [Online] Available: http://www.ekngvdw@puknet.puk.ac.za. (Accessed 13 July 2012) 
Van Heerden \& Heymans

\section{APPENDIX}

TABLE 1: Trends in Dividend per share (cents): 2007-2011

\begin{tabular}{ccccccc}
\hline & ABSA & FirstRand & Investec & Nedbank & Standard Bank & $\begin{array}{c}\text { Average per } \\
\text { year }\end{array}$ \\
\hline 2007 & 560.00 & 82.50 & 280.49 & 660.00 & 386.00 & 393.80 \\
2008 & 595.00 & 82.50 & 379.10 & 620.00 & 386.00 & 412.52 \\
2009 & 445.00 & 56.00 & 192.06 & 440.00 & 386.00 & 303.81 \\
2010 & 455.00 & 77.00 & 195.74 & 480.00 & 386.00 & 318.75 \\
2011 & 684.00 & 81.00 & 186.81 & 605.00 & 425.00 & 396.36 \\
\hline
\end{tabular}

Source: Data from the McGregor BFA database (2012)

TABLE 2: Trends in Earnings per share (cents): 2007-2011

\begin{tabular}{ccccccc}
\hline & ABSA & FirstRand & Investec & Nedbank & Standard Bank & $\begin{array}{c}\text { Average per } \\
\text { year }\end{array}$ \\
\hline 2007 & 1401.90 & 202.50 & 637.80 & 1485.00 & 1033.40 & 952.12 \\
2008 & 1466.20 & 191.50 & 753.66 & 1422.00 & 1002.00 & 967.07 \\
2009 & 1099.40 & 133.30 & 608.69 & 1010.00 & 771.10 & 724.50 \\
2010 & 1122.60 & 180.10 & 490.57 & 1104.00 & 735.20 & 726.49 \\
2011 & 1355.90 & 183.10 & 414.29 & 1365.00 & 887.20 & 841.10 \\
\hline
\end{tabular}

Source: Data from the McGregor BFA database (2012)

TABLE 3: Trends in ROE (\%): 2007-2011

\begin{tabular}{ccccccc}
\hline & ABSA & FirstRand & Investec & Nedbank & Standard Bank & Average peryear \\
\hline 2007 & 25.54 & 29.49 & 20.92 & 19.96 & 25.43 & 24.27 \\
2008 & 22.40 & 25.60 & 20.06 & 18.36 & 17.00 & 20.68 \\
2009 & 13.53 & 14.29 & 15.06 & 12.17 & 13.16 & 13.64 \\
2010 & 14.42 & 18.36 & 12.92 & 10.91 & 12.37 & 13.80 \\
2011 & 15.53 & 35.43 & 11.73 & 12.65 & 13.35 & 17.74 \\
\hline
\end{tabular}

Source: Data from the McGregor BFA database (2012) 
TABLE 4: The input and output variables for measuring relative liquidity efficiency

\begin{tabular}{llll}
\hline INPUT VARIABLES & Item ${ }^{*}$ & OUTPUT VARIABLES & Item $^{*}$ \\
\hline Total deposits & 1 & Other liabilities to public & 67 \\
Other borrowed funds & 41 & Other liabilities & 80 \\
Central bank money + gold & 103 & Deposits, loans \&advances & 110 \\
SA bank group funding & 111 & Contingent liabilities & $285-9$ \\
Investments \& bills, including & 195 & Other risk exposures & \\
trading portfolio assets & & & \\
\hline
\end{tabular}

Source: Compiled by the authors

The item numbers are indicated as reported in the BA 900 financial return statements.

TABLE 9: A comparison of the financial measures (including final rankings)

\begin{tabular}{|c|c|c|c|c|c|c|c|c|}
\hline & 2008 & $\begin{array}{l}\text { Index } \\
\text { value }\end{array}$ & 2009 & $\begin{array}{l}\text { Index } \\
\text { value }\end{array}$ & 2010 & $\begin{array}{l}\text { Index } \\
\text { value }\end{array}$ & 2011 & $\begin{array}{l}\text { Index } \\
\text { value }\end{array}$ \\
\hline \multirow{5}{*}{$\mathrm{P} / \mathcal{E}$ ratio } & Nedbank & 1 & Investec & 1 & FirstRand & 1 & ABSA & 1 \\
\hline & FirstRand & 2 & FirstRand & 2 & Nedbank & 2 & Nedbank & 2 \\
\hline & Investec & 3 & ABSA & 3 & ABSA & 3 & FirstRand & 3 \\
\hline & ABSA & 4 & Nedbank & 4 & Investec & 4 & $\begin{array}{l}\text { Standard } \\
\text { Bank }\end{array}$ & 4 \\
\hline & $\begin{array}{l}\text { Standard } \\
\text { Bank }\end{array}$ & 5 & $\begin{array}{l}\text { Standard } \\
\text { Bank }\end{array}$ & 5 & $\begin{array}{l}\text { Standard } \\
\text { Bank }\end{array}$ & 5 & Investec & 5 \\
\hline \multirow{5}{*}{$\begin{array}{l}\text { Price- } \\
\text { to-book } \\
\text { value }\end{array}$} & Investec & 1 & Investec & 1 & Investec & 1 & Investec & 1 \\
\hline & Nedbank & 2 & Nedbank & 2 & Nedbank & 2 & Nedbank & 2 \\
\hline & $\begin{array}{l}\text { Standard } \\
\text { Bank }\end{array}$ & 3 & FirstRand & 3 & ABSA & 3 & $\begin{array}{l}\text { Standard } \\
\text { Bank }\end{array}$ & 3 \\
\hline & ABSA & 4 & $\begin{array}{l}\text { Standard } \\
\text { Bank }\end{array}$ & 4 & $\begin{array}{l}\text { Standard } \\
\text { Bank }\end{array}$ & 4 & ABSA & 4 \\
\hline & FirstRand & 5 & ABSA & 5 & FirstRand & 5 & FirstRand & 5 \\
\hline \multirow{5}{*}{$\begin{array}{l}\text { Cash } \\
\text { flow } \\
\text { yield }\end{array}$} & Investec & 1 & Investec & 1 & Investec & 1 & Investec & 1 \\
\hline & $\begin{array}{l}\text { Standard } \\
\text { Bank }\end{array}$ & 2 & FirstRand & 2 & ABSA & 2 & FirstRand & 2 \\
\hline & ABSA & 3 & Nedbank & 3 & Nedbank & 3 & $\begin{array}{l}\text { Standard } \\
\text { Bank }\end{array}$ & 3 \\
\hline & Nedbank & 4 & ABSA & 4 & FirstRand & 4 & Nedbank & 4 \\
\hline & FirstRand & 5 & $\begin{array}{l}\text { Standard } \\
\text { Bank }\end{array}$ & 5 & $\begin{array}{l}\text { Standard } \\
\text { Bank }\end{array}$ & 5 & ABSA & 5 \\
\hline
\end{tabular}




\begin{tabular}{|c|c|c|c|c|c|c|c|c|}
\hline & 2008 & $\begin{array}{l}\text { Index } \\
\text { value }\end{array}$ & 2009 & $\begin{array}{l}\text { Index } \\
\text { value }\end{array}$ & 2010 & $\begin{array}{l}\text { Index } \\
\text { value }\end{array}$ & 2011 & $\begin{array}{l}\text { Index } \\
\text { value }\end{array}$ \\
\hline \multirow{6}{*}{$\begin{array}{l}\text { Current } \\
\text { ratio }\end{array}$} & Investec & 1 & Investec & 1 & Investec & 1 & Investec & 1 \\
\hline & FirstRand & 2 & FirstRand & 2 & FirstRand & 2 & Nedbank & 2 \\
\hline & $\begin{array}{l}\text { Standard } \\
\text { Bank }\end{array}$ & 3 & $\begin{array}{l}\text { Standard } \\
\text { Bank }\end{array}$ & 3 & $\begin{array}{l}\text { Standard } \\
\text { Bank }\end{array}$ & 3 & FirstRand & 3 \\
\hline & ABSA & 4 & ABSA & 4 & ABSA & 4 & $\begin{array}{l}\text { Standard } \\
\text { Bank }\end{array}$ & 4 \\
\hline & Nedbank & 5 & Nedbank & 5 & Nedbank & 5 & ABSA & 5 \\
\hline & 2008 & Total & 2009 & Total & 2010 & Total & 2011 & Total \\
\hline \multirow{5}{*}{$\begin{array}{l}\text { Ranking } \\
\text { totals }\end{array}$} & ABSA & 15 & ABSA & 16 & ABSA & 12 & ABSA & 15 \\
\hline & FirstRand & 14 & FirstRand & 9 & FirstRand & 12 & FirstRand & 13 \\
\hline & Investec & 6 & Investec & 4 & Investec & 7 & Investec & 8 \\
\hline & Nedbank & 12 & Nedbank & 14 & Nedbank & 12 & Nedbank & 10 \\
\hline & $\begin{array}{l}\text { Standard } \\
\text { Bank }\end{array}$ & 13 & $\begin{array}{l}\text { Standard } \\
\text { Bank }\end{array}$ & 17 & $\begin{array}{l}\text { Standard } \\
\text { Bank }\end{array}$ & 17 & $\begin{array}{l}\text { Standard } \\
\text { Bank }\end{array}$ & 14 \\
\hline \multicolumn{2}{|c|}{ Overall average } & \multicolumn{3}{|c|}{ Final ranking } & & & & \\
\hline ABSA & 14.50 & \multicolumn{2}{|c|}{ Investec } & 6.25 & & & & \\
\hline FirstRand & 12.00 & \multicolumn{2}{|c|}{ Nedbank } & 12.00 & & & & \\
\hline Investec & 6.25 & \multicolumn{2}{|c|}{ FirstRand } & 12.00 & & & & \\
\hline Nedbank & 12.00 & \multicolumn{2}{|l|}{ ABSA } & 14.50 & & & & \\
\hline $\begin{array}{l}\text { Standard } \\
\text { Bank }\end{array}$ & 15.25 & \multicolumn{2}{|c|}{$\begin{array}{l}\text { Standard } \\
\text { Bank }\end{array}$} & 15.25 & & & & \\
\hline
\end{tabular}

Source: Authors' analysis

TABLE 10: Yearly P/E ratios

\begin{tabular}{lccccc}
\hline & ABSA & FirstRand & Investec & Nedbank & Standard Bank \\
\hline 2008 & 7.34 & 7.13 & 7.28 & 6.55 & 8.28 \\
2009 & 11.49 & 10.20 & 5.69 & 11.80 & 12.92 \\
2010 & 11.92 & 10.62 & 12.60 & 11.58 & 14.04 \\
2011 & 10.43 & 10.66 & 12.67 & 10.54 & 11.08 \\
\hline
\end{tabular}

Source: Data from the McGregor BFA database (2012) 
TABLE 11: Yearly Price-to-book value

\begin{tabular}{cccccc}
\hline & ABSA & FirstRand & Investec & Nedbank & Standard Bank \\
\hline 2008 & 1.54 & 1.60 & 0.82 & 1.09 & 1.44 \\
2009 & 1.79 & 1.56 & 0.54 & 1.31 & 1.75 \\
2010 & 1.70 & 1.95 & 1.01 & 1.30 & 1.78 \\
2011 & 1.63 & 1.88 & 0.80 & 1.34 & 1.50 \\
\hline
\end{tabular}

Source: Data from the McGregor BFA database (2012)

TABLE 12: Yearly cash flow yield

\begin{tabular}{lccccc}
\hline & ABSA & FirstRand & Investec & Nedbank & Standard Bank \\
\hline 2008 & 0.34 & 0.21 & 0.51 & 0.33 & 0.38 \\
2009 & 0.22 & 0.34 & 0.45 & 0.23 & 0.18 \\
2010 & 0.24 & 0.17 & 0.31 & 0.23 & 0.14 \\
2011 & 0.18 & 0.23 & 0.37 & 0.20 & 0.21 \\
\hline
\end{tabular}

Source: Data from the McGregor BFA database (2012)

TABLE 13: Yearly current ratio

\begin{tabular}{lccccc}
\hline & ABSA & FirstRand & Investec & Nedbank & Standard Bank \\
\hline 2008 & 0.32 & 0.74 & 0.98 & 0.12 & 0.70 \\
2009 & 0.22 & 0.96 & 1.09 & 0.10 & 0.65 \\
2010 & 0.25 & 0.88 & 1.10 & 0.13 & 0.70 \\
2011 & 0.31 & 0.89 & 1.04 & 1.00 & 0.64 \\
\hline
\end{tabular}

Source: Data from the McGregor BFA database (2012)

TABLE 14: Efficiency estimates: ABSA

\begin{tabular}{lcccccc}
\hline & $\begin{array}{c}\text { Technical } \\
\text { efficiency: } \\
\text { input- } \\
\text { orientated }\end{array}$ & $\begin{array}{c}\text { Scale } \\
\text { efficiency }\end{array}$ & $\begin{array}{c}\text { Return to } \\
\text { scale }\end{array}$ & $\begin{array}{c}\text { Technical } \\
\text { efficiency: } \\
\text { output- } \\
\text { orientated }\end{array}$ & $\begin{array}{c}\text { Scale } \\
\text { efficiency }\end{array}$ & $\begin{array}{c}\text { Return to } \\
\text { scale }\end{array}$ \\
\hline Jan-08 & 1.00 & 1.00 & - & 1.00 & 1.00 & - \\
Feb-08 & 1.00 & 1.00 & - & 1.00 & 1.00 & - \\
Mar-08 & 1.00 & 1.00 & - & 1.00 & 1.00 & - \\
Apr-08 & 1.00 & 1.00 & - & 1.00 & 1.00 & - \\
May-08 & 1.00 & 1.00 & - & 1.00 & 1.00 & - \\
Jun-08 & 1.00 & 1.00 & - & 1.00 & 1.00 & -
\end{tabular}




\begin{tabular}{|c|c|c|c|c|c|c|}
\hline & $\begin{array}{l}\text { Technical } \\
\text { efficiency: } \\
\text { input- } \\
\text { orientated }\end{array}$ & $\begin{array}{c}\text { Scale } \\
\text { efficiency }\end{array}$ & $\begin{array}{c}\text { Return to } \\
\text { scale }\end{array}$ & $\begin{array}{c}\text { Technical } \\
\text { efficiency: } \\
\text { output- } \\
\text { orientated }\end{array}$ & $\begin{array}{c}\text { Scale } \\
\text { efficiency }\end{array}$ & $\begin{array}{c}\text { Return to } \\
\text { scale }\end{array}$ \\
\hline Jul-08 & 1.00 & 1.00 & - & 1.00 & 1.00 & - \\
\hline Aug-08 & 1.00 & 1.00 & - & 1.00 & 1.00 & - \\
\hline Sep-08 & 1.00 & 1.00 & - & 1.00 & 1.00 & - \\
\hline $0 c t-08$ & 1.00 & 0.98 & Decrease & 1.00 & 0.98 & Decrease \\
\hline Nov-08 & 1.00 & 0.97 & Decrease & 1.00 & 0.97 & Decrease \\
\hline Dec-08 & 0.96 & 1.00 & Decrease & 0.97 & 0.99 & Decrease \\
\hline Jan-09 & 0.99 & 0.98 & Decrease & 0.99 & 0.97 & Decrease \\
\hline Feb-09 & 0.96 & 0.99 & Decrease & 0.97 & 0.98 & Decrease \\
\hline Mar-09 & 0.94 & 0.99 & Decrease & 0.95 & 0.98 & Decrease \\
\hline Apr-09 & 0.95 & 1.00 & Decrease & 0.95 & 0.99 & Decrease \\
\hline May-09 & 0.93 & 1.00 & - & 0.95 & 0.99 & Decrease \\
\hline Jun-09 & 0.96 & 0.99 & Decrease & 0.97 & 0.98 & Decrease \\
\hline Jul-09 & 0.98 & 0.98 & Decrease & 0.98 & 0.98 & Decrease \\
\hline Aug-09 & 1.00 & 0.99 & Decrease & 1.00 & 0.99 & Decrease \\
\hline Sep-09 & 0.98 & 0.99 & Decrease & 0.99 & 0.98 & Decrease \\
\hline $0 \mathrm{ct}-09$ & 1.00 & 0.98 & Decrease & 1.00 & 0.98 & Decrease \\
\hline Nov-09 & 0.95 & 1.00 & Decrease & 0.96 & 0.99 & Decrease \\
\hline Dec-09 & 0.97 & 0.99 & Decrease & 0.97 & 0.99 & Decrease \\
\hline Jan-10 & 0.98 & 1.00 & Decrease & 0.98 & 0.99 & Decrease \\
\hline Feb-10 & 1.00 & 0.98 & Decrease & 1.00 & 0.98 & Decrease \\
\hline Mar-10 & 0.95 & 1.00 & - & 0.96 & 1.00 & Decrease \\
\hline Apr-10 & 0.96 & 1.00 & - & 0.96 & 1.00 & Decrease \\
\hline May-10 & 0.98 & 1.00 & Decrease & 0.99 & 1.00 & Decrease \\
\hline Jun-10 & 0.96 & 1.00 & - & 0.96 & 1.00 & Decrease \\
\hline Jul-10 & 1.00 & 1.00 & - & 1.00 & 1.00 & - \\
\hline Aug-10 & 1.00 & 1.00 & - & 1.00 & 1.00 & - \\
\hline Sep-10 & 1.00 & 1.00 & - & 1.00 & 1.00 & - \\
\hline $0 \mathrm{ct}-10$ & 0.95 & 1.00 & - & 0.95 & 1.00 & - \\
\hline Nov-10 & 0.96 & 1.00 & - & 0.97 & 0.98 & Decrease \\
\hline Dec-10 & 1.00 & 1.00 & Increase & 1.00 & 1.00 & Increase \\
\hline Jan-11 & 1.00 & 1.00 & - & 1.00 & 1.00 & - \\
\hline Feb-11 & 1.00 & 1.00 & - & 1.00 & 1.00 & - \\
\hline Mar-11 & 1.00 & 1.00 & - & 1.00 & 1.00 & - \\
\hline Apr-11 & 0.99 & 1.00 & - & 1.00 & 1.00 & Decrease \\
\hline May-11 & 1.00 & 1.00 & - & 1.00 & 1.00 & - \\
\hline Jun-11 & 0.96 & 1.00 & - & 0.96 & 1.00 & Decrease \\
\hline
\end{tabular}




\begin{tabular}{lcccccc}
\hline & $\begin{array}{c}\text { Technical } \\
\text { efficiency: } \\
\text { input- } \\
\text { orientated }\end{array}$ & $\begin{array}{c}\text { Scale } \\
\text { efficiency }\end{array}$ & $\begin{array}{c}\text { Return to } \\
\text { scale }\end{array}$ & $\begin{array}{c}\text { Technical } \\
\text { efficiency: } \\
\text { output- } \\
\text { orientated }\end{array}$ & $\begin{array}{c}\text { Scale } \\
\text { efficiency }\end{array}$ & $\begin{array}{c}\text { Return to } \\
\text { scale }\end{array}$ \\
\hline Jul-11 & 0.96 & 1.00 & Decrease & 0.97 & 0.99 & Decrease \\
Aug-11 & 0.96 & 1.00 & Increase & 0.95 & 1.00 & Increase \\
Sep-11 & 1.00 & 1.00 & - & 1.00 & 1.00 & - \\
Oct-11 & 0.96 & 1.00 & Increase & 0.96 & 1.00 & - \\
Nov-11 & 0.92 & 1.00 & Increase & 0.92 & 1.00 & - \\
Dec-11 & 0.93 & 1.00 & Increase & 0.93 & 1.00 & Decrease \\
Jan-12 & 0.93 & 1.00 & Increase & 0.93 & 1.00 & - \\
Feb-12 & 0.94 & 1.00 & - & 0.94 & 1.00 & - \\
Mar-12 & 1.00 & 1.00 & - & 1.00 & 1.00 & - \\
Apr-12 & 1.00 & 1.00 & - & 1.00 & 1.00 & - \\
\hline Ave & 0.98 & 1.00 & & 0.98 & 0.99 & \\
\hline
\end{tabular}

Source: Authors'analysis

TABLE 15: Efficiency estimates: Standard Bank

\begin{tabular}{lcccccc}
\hline & $\begin{array}{c}\text { Technical } \\
\text { efficiency: } \\
\text { input- } \\
\text { orientated }\end{array}$ & $\begin{array}{c}\text { Scale } \\
\text { efficiency }\end{array}$ & $\begin{array}{c}\text { Returnto } \\
\text { scale }\end{array}$ & $\begin{array}{c}\text { Technical } \\
\text { efficiency: } \\
\text { output- } \\
\text { orientated }\end{array}$ & $\begin{array}{c}\text { Scale } \\
\text { efficiency }\end{array}$ & $\begin{array}{c}\text { Return to } \\
\text { scale }\end{array}$ \\
\hline Jan-08 & 1.00 & 1.00 & - & 1.00 & 1.00 & - \\
Feb-08 & 1.00 & 1.00 & - & 1.00 & 1.00 & - \\
Mar-08 & 1.00 & 1.00 & - & 1.00 & 1.00 & - \\
Apr-08 & 0.97 & 1.00 & Increase & 0.97 & 1.00 & - \\
May-08 & 1.00 & 1.00 & - & 1.00 & 1.00 & - \\
Jun-08 & 1.00 & 1.00 & - & 1.00 & 1.00 & - \\
Jul-08 & 1.00 & 1.00 & - & 1.00 & 1.00 & - \\
Aug-08 & 1.00 & 1.00 & - & 1.00 & 1.00 & - \\
Sep-08 & 1.00 & 0.99 & Decrease & 1.00 & 0.99 & Decrease \\
Oct-08 & 1.00 & 1.00 & - & 1.00 & 1.00 & - \\
Nov-08 & 1.00 & 1.00 & - & 1.00 & 1.00 & - \\
Dec-08 & 1.00 & 1.00 & Decrease & 1.00 & 1.00 & Decrease \\
Jan-09 & 1.00 & 1.00 & - & 1.00 & 1.00 & - \\
Feb-09 & 1.00 & 1.00 & - & 1.00 & 1.00 & - \\
Mar-09 & 0.97 & 1.00 & Decrease & 0.98 & 0.99 & Decrease \\
Apr-09 & 1.00 & 1.00 & - & 1.00 & 1.00 & - \\
May-09 & 1.00 & 1.00 & - & 1.00 & 1.00 & - \\
Jun-09 & 1.00 & 1.00 & Decrease & 1.00 & 1.00 & Decrease
\end{tabular}




\begin{tabular}{|c|c|c|c|c|c|c|}
\hline & $\begin{array}{l}\text { Technical } \\
\text { efficiency: } \\
\text { input- } \\
\text { orientated }\end{array}$ & $\begin{array}{c}\text { Scale } \\
\text { efficiency }\end{array}$ & $\begin{array}{c}\text { Return to } \\
\text { scale }\end{array}$ & $\begin{array}{l}\text { Technical } \\
\text { efficiency: } \\
\text { output- } \\
\text { orientated }\end{array}$ & $\begin{array}{c}\text { Scale } \\
\text { efficiency }\end{array}$ & $\begin{array}{c}\text { Return to } \\
\text { scale }\end{array}$ \\
\hline Jul-09 & 0.98 & 1.00 & - & 0.98 & 1.00 & Decrease \\
\hline Aug-09 & 0.99 & 1.00 & Decrease & 0.99 & 1.00 & Decrease \\
\hline Sep-09 & 0.98 & 1.00 & Decrease & 0.98 & 1.00 & Decrease \\
\hline $0 c t-09$ & 1.00 & 1.00 & - & 1.00 & 1.00 & - \\
\hline Nov-09 & 1.00 & 1.00 & - & 1.00 & 1.00 & - \\
\hline Dec-09 & 1.00 & 1.00 & - & 1.00 & 1.00 & - \\
\hline Jan-10 & 1.00 & 1.00 & - & 1.00 & 1.00 & - \\
\hline Feb-10 & 1.00 & 1.00 & - & 1.00 & 1.00 & - \\
\hline Mar-10 & 1.00 & 1.00 & - & 1.00 & 1.00 & - \\
\hline Apr-10 & 1.00 & 1.00 & - & 1.00 & 1.00 & - \\
\hline May-10 & 0.95 & 1.00 & - & 0.95 & 1.00 & - \\
\hline Jun-10 & 0.96 & 1.00 & Decrease & 0.97 & 1.00 & Decrease \\
\hline Jul-10 & 1.00 & 1.00 & - & 1.00 & 1.00 & - \\
\hline Aug-10 & 0.98 & 1.00 & Increase & 0.98 & 1.00 & Increase \\
\hline Sep-10 & 1.00 & 1.00 & - & 1.00 & 1.00 & - \\
\hline $0 c t-10$ & 1.00 & 1.00 & - & 1.00 & 1.00 & - \\
\hline Nov-10 & 0.98 & 1.00 & - & 0.98 & 1.00 & - \\
\hline Dec-10 & 1.00 & 1.00 & - & 1.00 & 1.00 & - \\
\hline Jan-11 & 1.00 & 1.00 & - & 1.00 & 1.00 & - \\
\hline Feb-11 & 1.00 & 1.00 & - & 1.00 & 1.00 & - \\
\hline Mar-11 & 1.00 & 1.00 & - & 1.00 & 1.00 & - \\
\hline Apr-11 & 0.96 & 1.00 & Increase & 0.96 & 1.00 & - \\
\hline May-11 & 0.99 & 0.97 & Decrease & 0.99 & 0.97 & Decrease \\
\hline Jun-11 & 0.96 & 1.00 & - & 0.96 & 1.00 & - \\
\hline Jul-11 & 0.97 & 1.00 & - & 0.97 & 1.00 & - \\
\hline Aug-11 & 0.95 & 1.00 & - & 0.95 & 1.00 & - \\
\hline Sep-11 & 1.00 & 1.00 & - & 1.00 & 1.00 & - \\
\hline $0 c t-11$ & 1.00 & 1.00 & - & 1.00 & 1.00 & - \\
\hline Nov-11 & 1.00 & 0.99 & Decrease & 1.00 & 0.99 & Decrease \\
\hline Dec-11 & 1.00 & 0.99 & Decrease & 1.00 & 0.99 & Decrease \\
\hline Jan-12 & 1.00 & 1.00 & - & 1.00 & 1.00 & - \\
\hline Feb-12 & 1.00 & 1.00 & Decrease & 1.00 & 1.00 & Decrease \\
\hline Mar-12 & 1.00 & 1.00 & - & 1.00 & 1.00 & - \\
\hline Apr-12 & 1.00 & 1.00 & - & 1.00 & 1.00 & - \\
\hline Average & 0.99 & 1.00 & & 0.99 & 1.00 & \\
\hline
\end{tabular}

Source: Authors' analysis 
TABLE 16: Efficiency estimates: Nedbank

\begin{tabular}{|c|c|c|c|c|c|c|}
\hline & $\begin{array}{c}\text { Technical } \\
\text { efficiency: } \\
\text { input- } \\
\text { orientated }\end{array}$ & $\begin{array}{c}\text { Scale } \\
\text { efficiency }\end{array}$ & $\begin{array}{c}\text { Return to } \\
\text { scale }\end{array}$ & $\begin{array}{l}\text { Technical } \\
\text { efficiency: } \\
\text { output- } \\
\text { orientated }\end{array}$ & $\begin{array}{c}\text { Scale } \\
\text { efficiency }\end{array}$ & $\begin{array}{c}\text { Return to } \\
\text { scale }\end{array}$ \\
\hline Jan-08 & 0.86 & 0.99 & Decrease & 0.86 & 0.99 & Decrease \\
\hline Feb-08 & 0.95 & 0.92 & Decrease & 0.96 & 0.92 & Decrease \\
\hline Mar-08 & 0.86 & 0.99 & Decrease & 0.86 & 0.99 & Decrease \\
\hline Apr-08 & 0.87 & 0.98 & Decrease & 0.87 & 0.98 & Decrease \\
\hline May-08 & 0.84 & 0.99 & Decrease & 0.84 & 0.99 & Decrease \\
\hline Jun-08 & 0.84 & 0.99 & Decrease & 0.84 & 0.99 & Decrease \\
\hline Jul-08 & 0.83 & 1.00 & Decrease & 0.83 & 0.99 & Decrease \\
\hline Aug-08 & 0.84 & 0.99 & Decrease & 0.85 & 0.99 & Decrease \\
\hline Sep-08 & 0.85 & 0.98 & Decrease & 0.85 & 0.98 & Decrease \\
\hline $0 \mathrm{ct}-08$ & 0.84 & 0.99 & Decrease & 0.84 & 0.99 & Decrease \\
\hline Nov-08 & 0.82 & 1.00 & Decrease & 0.82 & 0.99 & Decrease \\
\hline Dec-08 & 0.82 & 1.00 & Decrease & 0.83 & 0.99 & Decrease \\
\hline Jan-09 & 0.84 & 0.99 & Decrease & 0.84 & 0.98 & Decrease \\
\hline Feb-09 & 1.00 & 0.87 & Decrease & 1.00 & 0.87 & Decrease \\
\hline Mar-09 & 0.90 & 0.96 & Decrease & 0.91 & 0.95 & Decrease \\
\hline Apr-09 & 0.87 & 0.98 & Decrease & 0.88 & 0.96 & Decrease \\
\hline May-09 & 0.86 & 0.98 & Decrease & 0.87 & 0.96 & Decrease \\
\hline Jun-09 & 0.85 & 0.98 & Decrease & 0.85 & 0.98 & Decrease \\
\hline Jul-09 & 0.92 & 0.91 & Decrease & 0.93 & 0.90 & Decrease \\
\hline Aug-09 & 0.89 & 0.97 & Decrease & 0.89 & 0.96 & Decrease \\
\hline Sep-09 & 0.87 & 0.97 & Decrease & 0.88 & 0.96 & Decrease \\
\hline 0 ct-09 & 0.86 & 0.97 & Decrease & 0.87 & 0.96 & Decrease \\
\hline Nov-09 & 0.87 & 0.97 & Decrease & 0.87 & 0.96 & Decrease \\
\hline Dec-09 & 0.89 & 0.95 & Decrease & 0.90 & 0.95 & Decrease \\
\hline Jan-10 & 0.88 & 0.96 & Decrease & 0.89 & 0.95 & Decrease \\
\hline Feb-10 & 0.88 & 1.00 & Decrease & 0.89 & 0.99 & Decrease \\
\hline Mar-10 & 0.89 & 0.98 & Decrease & 0.90 & 0.97 & Decrease \\
\hline Apr-10 & 1.00 & 0.95 & Decrease & 1.00 & 0.95 & Decrease \\
\hline May-10 & 1.00 & 0.92 & Decrease & 1.00 & 0.92 & Decrease \\
\hline Jun-10 & 0.98 & 0.92 & Decrease & 0.98 & 0.92 & Decrease \\
\hline Jul-10 & 1.00 & 0.88 & Decrease & 1.00 & 0.88 & Decrease \\
\hline Aug- 10 & 0.98 & 0.98 & Decrease & 0.99 & 0.98 & Decrease \\
\hline Sep-10 & 0.96 & 0.98 & Decrease & 0.96 & 0.98 & Decrease \\
\hline $0 \mathrm{ct}-10$ & 0.98 & 1.00 & Decrease & 0.98 & 0.99 & Decrease \\
\hline Nov-10 & 0.98 & 1.00 & - & 0.99 & 1.00 & Decrease \\
\hline
\end{tabular}




\begin{tabular}{|c|c|c|c|c|c|c|}
\hline & $\begin{array}{l}\text { Technical } \\
\text { efficiency: } \\
\text { input- } \\
\text { orientated }\end{array}$ & $\begin{array}{c}\text { Scale } \\
\text { efficiency }\end{array}$ & $\begin{array}{c}\text { Return to } \\
\text { scale }\end{array}$ & $\begin{array}{l}\text { Technical } \\
\text { efficiency: } \\
\text { output- } \\
\text { orientated }\end{array}$ & $\begin{array}{c}\text { Scale } \\
\text { efficiency }\end{array}$ & $\begin{array}{c}\text { Return to } \\
\text { scale }\end{array}$ \\
\hline Dec-10 & 0.99 & 1.00 & Decrease & 0.99 & 1.00 & Decrease \\
\hline Jan-11 & 1.00 & 1.00 & - & 1.00 & 1.00 & - \\
\hline Feb-11 & 1.00 & 1.00 & - & 1.00 & 1.00 & - \\
\hline Mar-11 & 1.00 & 1.00 & - & 1.00 & 1.00 & - \\
\hline Apr-11 & 1.00 & 1.00 & - & 1.00 & 1.00 & - \\
\hline May-11 & 1.00 & 1.00 & - & 1.00 & 1.00 & - \\
\hline Jun-11 & 0.98 & 1.00 & Decrease & 0.99 & 1.00 & Decrease \\
\hline Jul-11 & 0.98 & 1.00 & - & 0.98 & 1.00 & - \\
\hline Aug-11 & 0.98 & 1.00 & Increase & 0.98 & 1.00 & - \\
\hline Sep-11 & 0.98 & 1.00 & Decrease & 0.98 & 1.00 & Decrease \\
\hline $0 \mathrm{ct}-11$ & 0.99 & 1.00 & - & 0.99 & 1.00 & - \\
\hline Nov-11 & 0.98 & 1.00 & - & 0.98 & 1.00 & - \\
\hline Dec-11 & 0.99 & 1.00 & Decrease & 0.99 & 1.00 & Decrease \\
\hline Jan-12 & 1.00 & 1.00 & - & 1.00 & 1.00 & - \\
\hline Feb-12 & 1.00 & 1.00 & - & 1.00 & 1.00 & - \\
\hline Mar-12 & 1.00 & 1.00 & - & 1.00 & 1.00 & - \\
\hline Apr-12 & 1.00 & 0.99 & Decrease & 1.00 & 0.99 & Decrease \\
\hline Average & 0.93 & 0.98 & & 0.93 & 0.97 & \\
\hline
\end{tabular}

Source: Authors' analysis

TABLE 17: عfficiency estimates: FirstRand Bank

\begin{tabular}{lcccccc}
\hline & $\begin{array}{c}\text { Technical } \\
\text { efficiency: } \\
\text { input- } \\
\text { orientated }\end{array}$ & $\begin{array}{c}\text { Scale } \\
\text { efficiency }\end{array}$ & $\begin{array}{c}\text { Return to } \\
\text { scale }\end{array}$ & $\begin{array}{c}\text { Technical } \\
\text { efficiency: } \\
\text { output- } \\
\text { orientated }\end{array}$ & $\begin{array}{c}\text { Scale } \\
\text { efficiency }\end{array}$ & $\begin{array}{c}\text { Return to } \\
\text { scale }\end{array}$ \\
\hline Jan-08 & 1.00 & 1.00 & - & 1.00 & 1.00 & - \\
Feb-08 & 1.00 & 1.00 & - & 1.00 & 1.00 & - \\
Mar-08 & 1.00 & 1.00 & - & 1.00 & 1.00 & - \\
Apr-08 & 1.00 & 1.00 & Decrease & 1.00 & 1.00 & Decrease \\
May-08 & 1.00 & 1.00 & - & 1.00 & 1.00 & - \\
Jun-08 & 0.98 & 1.00 & Increase & 0.98 & 1.00 & Increase \\
Jul-08 & 0.98 & 1.00 & Increase & 0.98 & 1.00 & Increase \\
Aug-08 & 0.96 & 1.00 & Increase & 0.96 & 1.00 & Increase \\
Sep-08 & 0.98 & 1.00 & Increase & 0.98 & 1.00 & Increase \\
Oct-08 & 1.00 & 1.00 & - & 1.00 & 1.00 & - \\
Nov-08 & 1.00 & 1.00 & - & 1.00 & 1.00 & -
\end{tabular}




\begin{tabular}{|c|c|c|c|c|c|c|}
\hline & $\begin{array}{l}\text { Technical } \\
\text { efficiency: } \\
\text { input- } \\
\text { orientated }\end{array}$ & $\begin{array}{c}\text { Scale } \\
\text { efficiency }\end{array}$ & $\begin{array}{l}\text { Return to } \\
\text { scale }\end{array}$ & $\begin{array}{l}\text { Technical } \\
\text { efficiency: } \\
\text { output- } \\
\text { orientated }\end{array}$ & $\begin{array}{c}\text { Scale } \\
\text { efficiency }\end{array}$ & $\begin{array}{c}\text { Return to } \\
\text { scale }\end{array}$ \\
\hline Dec-08 & 0.96 & 1.00 & Increase & 0.96 & 1.00 & Increase \\
\hline Jan-09 & 0.98 & 1.00 & Increase & 0.98 & 1.00 & Increase \\
\hline Feb-09 & 0.97 & 1.00 & Increase & 0.97 & 1.00 & Increase \\
\hline Mar-09 & 0.95 & 1.00 & Increase & 0.95 & 1.00 & - \\
\hline Apr-09 & 0.95 & 1.00 & Increase & 0.95 & 1.00 & Increase \\
\hline May-09 & 0.94 & 1.00 & Increase & 0.94 & 1.00 & Increase \\
\hline Jun-09 & 0.93 & 1.00 & Increase & 0.93 & 1.00 & - \\
\hline Jul-09 & 0.94 & 1.00 & Increase & 0.94 & 1.00 & - \\
\hline Aug-09 & 0.94 & 1.00 & Increase & 0.94 & 1.00 & - \\
\hline Sep-09 & 0.91 & 1.00 & Increase & 0.91 & 1.00 & - \\
\hline 0 ct-09 & 0.93 & 1.00 & Increase & 0.92 & 1.00 & - \\
\hline Nov-09 & 0.93 & 1.00 & Increase & 0.93 & 1.00 & - \\
\hline Dec-09 & 0.92 & 1.00 & Increase & 0.92 & 1.00 & - \\
\hline Jan-10 & 0.93 & 1.00 & Increase & 0.93 & 1.00 & - \\
\hline Feb-10 & 0.92 & 1.00 & Increase & 0.92 & 1.00 & - \\
\hline Mar-10 & 0.92 & 1.00 & Increase & 0.92 & 1.00 & Decrease \\
\hline Apr-10 & 0.90 & 1.00 & Increase & 0.90 & 1.00 & Decrease \\
\hline May-10 & 0.92 & 1.00 & Increase & 0.92 & 1.00 & Decrease \\
\hline Jun-10 & 0.93 & 0.99 & Increase & 0.92 & 1.00 & - \\
\hline Jul-10 & 1.00 & 1.00 & - & 1.00 & 1.00 & - \\
\hline Aug-10 & 0.98 & 0.99 & Increase & 0.98 & 1.00 & Increase \\
\hline Sep-10 & 0.93 & 1.00 & Increase & 0.93 & 1.00 & Decrease \\
\hline $0 c t-10$ & 0.92 & 1.00 & Increase & 0.92 & 1.00 & Decrease \\
\hline Nov-10 & 0.90 & 1.00 & Increase & 0.90 & 1.00 & Decrease \\
\hline Dec-10 & 0.91 & 1.00 & Increase & 0.92 & 1.00 & Decrease \\
\hline Jan-11 & 0.90 & 1.00 & Increase & 0.90 & 1.00 & Decrease \\
\hline Feb-11 & 0.91 & 1.00 & Increase & 0.91 & 1.00 & Decrease \\
\hline Mar-11 & 0.91 & 1.00 & Increase & 0.91 & 1.00 & Decrease \\
\hline Apr-11 & 0.91 & 1.00 & - & 0.92 & 0.99 & Decrease \\
\hline May-11 & 0.91 & 1.00 & - & 0.92 & 0.99 & Decrease \\
\hline Jun-11 & 0.92 & 1.00 & Decrease & 0.94 & 0.99 & Decrease \\
\hline Jul-1l & 0.93 & 1.00 & Decrease & 0.94 & 0.99 & Decrease \\
\hline Aug-11 & 0.92 & 1.00 & Decrease & 0.94 & 0.99 & Decrease \\
\hline Sep-11 & 0.93 & 0.99 & Decrease & 0.94 & 0.97 & Decrease \\
\hline $0 c t-11$ & 0.90 & 1.00 & Decrease & 0.92 & 0.98 & Decrease \\
\hline Nov-11 & 0.91 & 0.99 & Decrease & 0.92 & 0.98 & Decrease \\
\hline
\end{tabular}




\begin{tabular}{lcccccc}
\hline & $\begin{array}{c}\text { Technical } \\
\text { efficiency: } \\
\text { input- } \\
\text { orientated }\end{array}$ & $\begin{array}{c}\text { Scale } \\
\text { efficiency }\end{array}$ & $\begin{array}{c}\text { Return to } \\
\text { scale }\end{array}$ & $\begin{array}{c}\text { Technical } \\
\text { efficiency: } \\
\text { output- } \\
\text { orientated }\end{array}$ & $\begin{array}{c}\text { Scale } \\
\text { efficiency }\end{array}$ & $\begin{array}{c}\text { Return to } \\
\text { scale }\end{array}$ \\
\hline Dec-11 & 0.90 & 1.00 & Decrease & 0.91 & 0.98 & Decrease \\
Jan-12 & 0.91 & 1.00 & Decrease & 0.92 & 0.98 & Decrease \\
Feb-12 & 0.92 & 1.00 & Decrease & 0.93 & 0.98 & Decrease \\
Mar-12 & 1.00 & 1.00 & - & 1.00 & 1.00 & - \\
Apr-12 & 1.00 & 1.00 & - & 1.00 & 1.00 & - \\
Average & 0.94 & 1.00 & & 0.95 & 1.00 & - \\
\hline
\end{tabular}

Source: Authors' analysis

TABLE 18: عfficiency estimates: Investec Bank

\begin{tabular}{|c|c|c|c|c|c|c|}
\hline & $\begin{array}{l}\text { Technical } \\
\text { efficiency: } \\
\text { input- } \\
\text { orientated }\end{array}$ & $\begin{array}{c}\text { Scale } \\
\text { efficiency }\end{array}$ & $\begin{array}{c}\text { Return to } \\
\text { scale }\end{array}$ & $\begin{array}{c}\text { Technical } \\
\text { efficiency: } \\
\text { output- } \\
\text { orientated }\end{array}$ & $\begin{array}{c}\text { Scale } \\
\text { efficiency }\end{array}$ & $\begin{array}{c}\text { Return to } \\
\text { scale }\end{array}$ \\
\hline Jan-08 & 1.00 & 0.92 & Increase & 1.00 & 0.92 & Increase \\
\hline Feb-08 & 1.00 & 1.00 & - & 1.00 & 1.00 & - \\
\hline Mar-08 & 1.00 & 1.00 & - & 1.00 & 1.00 & - \\
\hline Apr-08 & 1.00 & 1.00 & - & 1.00 & 1.00 & - \\
\hline May-08 & 1.00 & 1.00 & Increase & 1.00 & 1.00 & Increase \\
\hline Jun-08 & 1.00 & 1.00 & - & 1.00 & 1.00 & - \\
\hline Jul-08 & 1.00 & 1.00 & - & 1.00 & 1.00 & - \\
\hline Aug-08 & 1.00 & 1.00 & - & 1.00 & 1.00 & - \\
\hline Sep-08 & 1.00 & 1.00 & - & 1.00 & 1.00 & - \\
\hline $0 c t-08$ & 1.00 & 1.00 & - & 1.00 & 1.00 & - \\
\hline Nov-08 & 1.00 & 1.00 & Increase & 1.00 & 1.00 & Increase \\
\hline Dec-08 & 1.00 & 1.00 & - & 1.00 & 1.00 & - \\
\hline Jan-09 & 0.99 & 0.99 & Increase & 0.99 & 0.99 & Increase \\
\hline Feb-09 & 1.00 & 1.00 & - & 1.00 & 1.00 & - \\
\hline Mar-09 & 0.96 & 0.99 & Increase & 0.95 & 1.00 & Increase \\
\hline Apr-09 & 1.00 & 1.00 & - & 1.00 & 1.00 & - \\
\hline May-09 & 1.00 & 1.00 & - & 1.00 & 1.00 & - \\
\hline Jun-09 & 1.00 & 1.00 & - & 1.00 & 1.00 & - \\
\hline Jul-09 & 0.91 & 1.00 & Increase & 0.91 & 1.00 & Increase \\
\hline Aug-09 & 0.88 & 0.99 & Increase & 0.87 & 1.00 & Increase \\
\hline Sep-09 & 0.87 & 0.98 & Increase & 0.86 & 1.00 & Increase \\
\hline 0ct-09 & 0.88 & 0.99 & Increase & 0.87 & 1.00 & Increase \\
\hline Nov-09 & 0.88 & 1.00 & Increase & 0.88 & 1.00 & - \\
\hline
\end{tabular}




\begin{tabular}{|c|c|c|c|c|c|c|}
\hline & $\begin{array}{l}\text { Technical } \\
\text { efficiency: } \\
\text { input- } \\
\text { orientated }\end{array}$ & $\begin{array}{c}\text { Scale } \\
\text { efficiency }\end{array}$ & $\begin{array}{l}\text { Return to } \\
\text { scale }\end{array}$ & $\begin{array}{l}\text { Technical } \\
\text { efficiency: } \\
\text { output- } \\
\text { orientated }\end{array}$ & $\begin{array}{c}\text { Scale } \\
\text { efficiency }\end{array}$ & $\begin{array}{c}\text { Return to } \\
\text { scale }\end{array}$ \\
\hline Dec-09 & 1.00 & 1.00 & - & 1.00 & 1.00 & - \\
\hline Jan-10 & 0.95 & 1.00 & Decrease & 0.96 & 0.99 & Decrease \\
\hline Feb-10 & 0.88 & 1.00 & - & 0.88 & 1.00 & Decrease \\
\hline Mar-10 & 0.85 & 0.98 & Increase & 0.84 & 0.99 & Increase \\
\hline Apr-10 & 0.84 & 0.97 & Increase & 0.82 & 0.99 & Increase \\
\hline May-10 & 0.84 & 0.98 & Increase & 0.82 & 1.00 & Increase \\
\hline Jun-10 & 0.82 & 1.00 & Increase & 0.82 & 1.00 & Decrease \\
\hline Jul-10 & 0.83 & 0.99 & Increase & 0.82 & 1.00 & Increase \\
\hline Aug-10 & 0.80 & 0.99 & Increase & 0.79 & 1.00 & Decrease \\
\hline Sep-10 & 0.81 & 0.98 & Increase & 0.80 & 1.00 & - \\
\hline $0 c t-10$ & 0.81 & 0.98 & Increase & 0.80 & 1.00 & Increase \\
\hline Nov-10 & 0.82 & 0.99 & Increase & 0.81 & 1.00 & Decrease \\
\hline Dec-10 & 0.85 & 0.98 & Increase & 0.84 & 1.00 & Increase \\
\hline Jan-11 & 0.83 & 0.99 & Increase & 0.82 & 1.00 & - \\
\hline Feb-11 & 0.84 & 0.99 & Increase & 0.84 & 1.00 & Decrease \\
\hline Mar-11 & 0.82 & 0.98 & Increase & 0.80 & 1.00 & Increase \\
\hline Apr-11 & 0.83 & 0.99 & Increase & 0.82 & 1.00 & Increase \\
\hline May-11 & 0.81 & 1.00 & Increase & 0.82 & 0.97 & Decrease \\
\hline Jun-11 & 1.00 & 1.00 & - & 1.00 & 1.00 & - \\
\hline Jul-1l & 0.79 & 1.00 & Increase & 0.83 & 0.95 & Decrease \\
\hline Aug-11 & 0.82 & 1.00 & Increase & 0.85 & 0.96 & Decrease \\
\hline Sep-11 & 0.77 & 0.96 & Increase & 0.74 & 1.00 & - \\
\hline 0ct-11 & 0.78 & 0.99 & Increase & 0.81 & 0.95 & Decrease \\
\hline Nov-11 & 0.81 & 0.99 & Decrease & 0.88 & 0.91 & Decrease \\
\hline Dec-11 & 0.80 & 1.00 & Increase & 0.81 & 0.98 & Decrease \\
\hline Jan-12 & 0.84 & 1.00 & Decrease & 0.87 & 0.96 & Decrease \\
\hline Feb-12 & 0.78 & 0.99 & Increase & 0.78 & 1.00 & - \\
\hline Mar-12 & 0.78 & 0.99 & Increase & 0.77 & 1.00 & - \\
\hline Apr-12 & 0.79 & 1.00 & - & 0.83 & 0.95 & Decrease \\
\hline Average & 0.90 & 0.99 & & 0.90 & 0.99 & \\
\hline
\end{tabular}

Source: Authors' analysis 


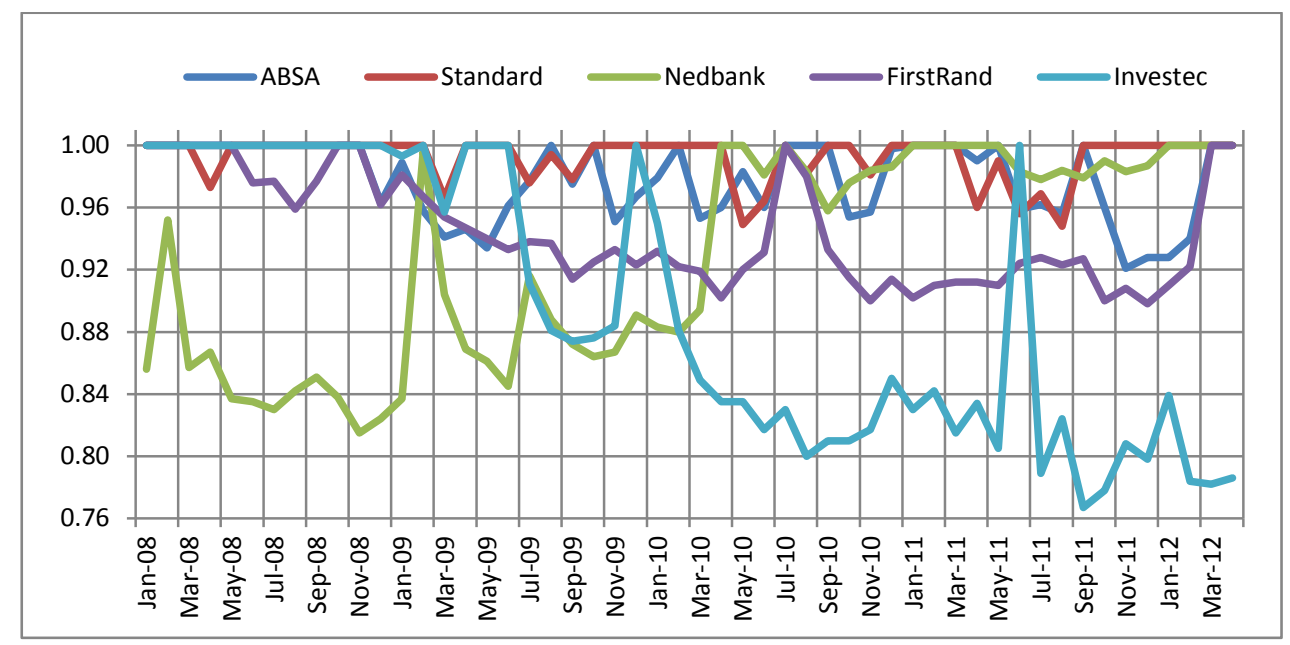

FIGURE 2: Comparison in terms of technical efficiency (input-orientated)

Source: Authors'compilation

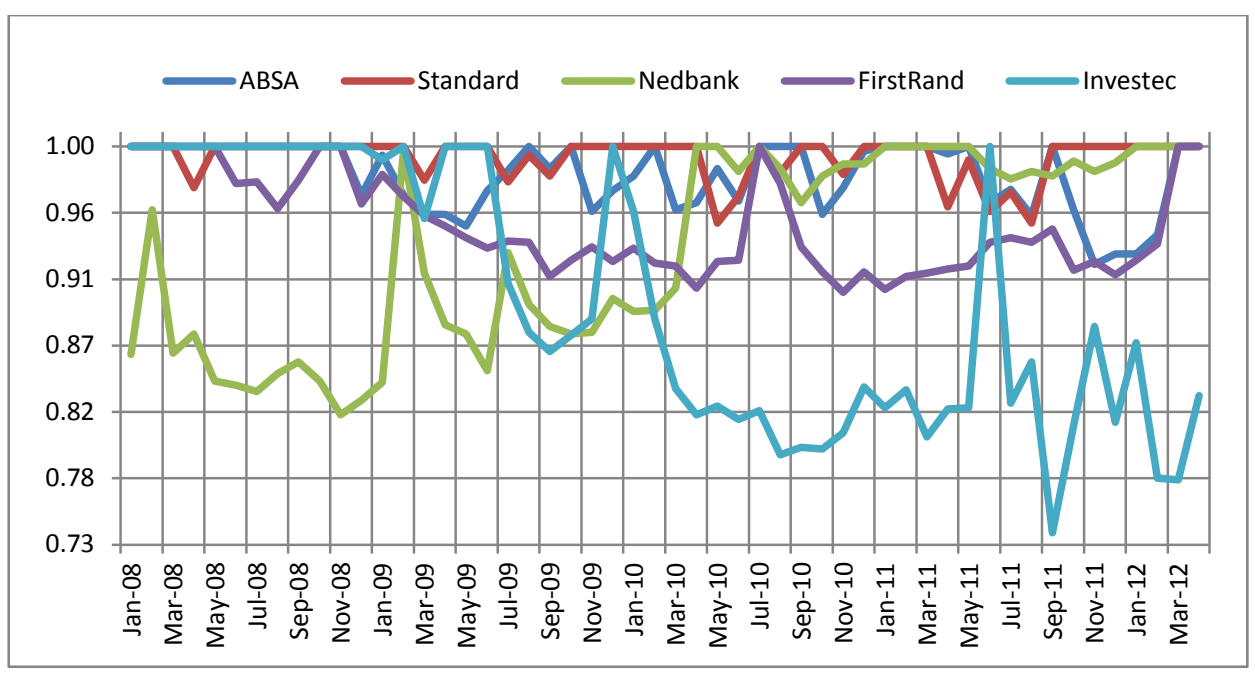

FIGURE 3: Comparison in terms of technical efficiency (output-orientated)

Source: Authors'compilation 


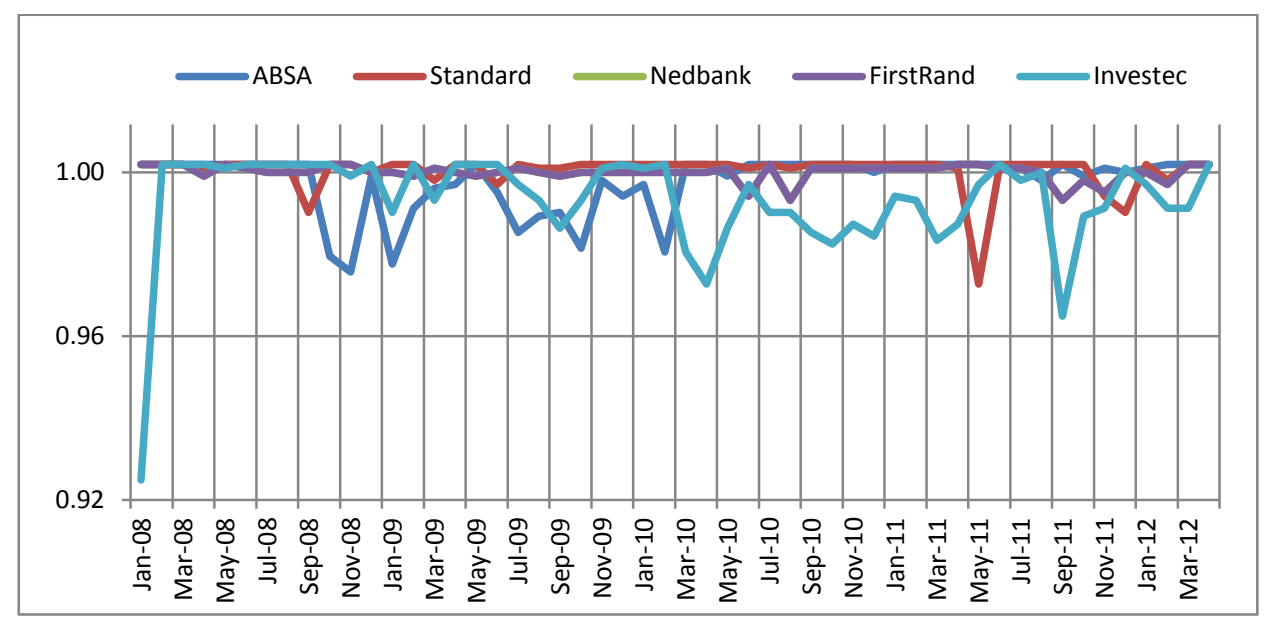

FIGURE 4: Comparison in terms of scale efficiency (input-orientated)

Source: Authors'compilation

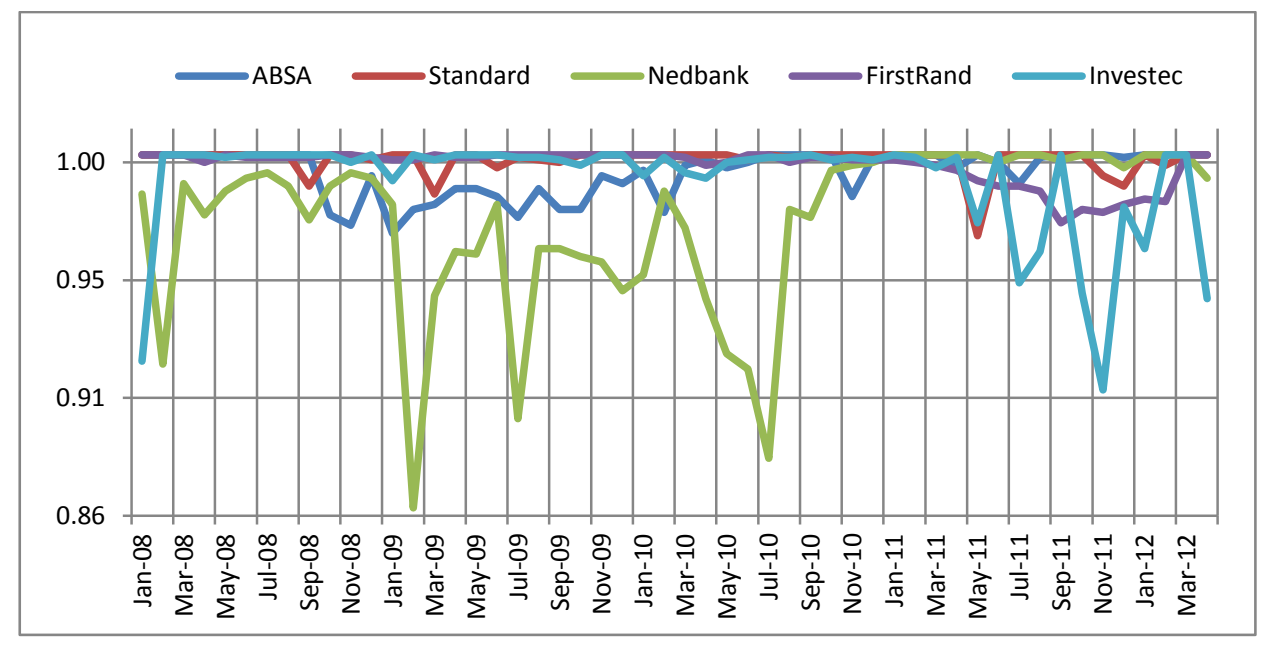

FIGURE 5: Comparison in terms of scale efficiency (output-orientated)

Source: Authors'compilation 
Van Heerden \& Heymans 